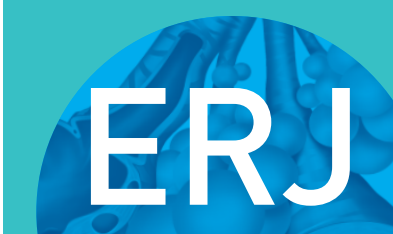

open research
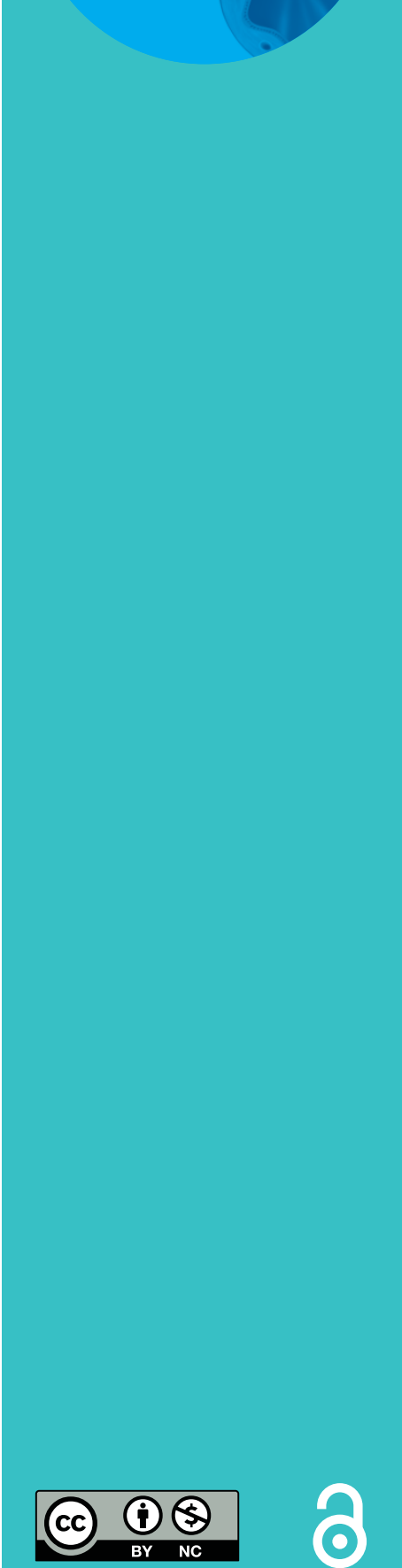

\section{Caffeine in preterm infants: where are we in 2020?}

\author{
Laura Moschino ${ }^{1}$, Sanja Zivanovic ${ }^{2,3}$, Caroline Hartley ${ }^{3}$, Daniele Trevisanuto ${ }^{1}$, \\ Eugenio Baraldi ${ }^{1}$ and Charles Christoph Roehr ${ }^{2,3}$
}

Affiliations: 'Dept of Women's and Children's Health, University of Padua, Padua, Italy. ${ }^{2}$ Newborn Services, John Radcliffe Hospital, Oxford University Hospitals NHS Foundation Trust, Oxford, UK. ${ }^{3}$ Dept of Paediatrics, University of Oxford, Oxford, UK.

Correspondence: Charles Christoph Roehr, Dept of Paediatrics, Newborn Services, John Radcliffe Hospital, Oxford University Hospitals NHS, Headley Way, Headington, Oxford OX3 9DU, UK. E-mail: Charles.Roehrdouh. nhs.uk

ABSTRACT The incidence of preterm birth is increasing, leading to a growing population with potential long-term pulmonary complications. Apnoea of prematurity (AOP) is one of the major challenges when treating preterm infants; it can lead to respiratory failure and the need for mechanical ventilation. Ventilating preterm infants can be associated with severe negative pulmonary and extrapulmonary outcomes, such as bronchopulmonary dysplasia (BPD), severe neurological impairment and death. Therefore, international guidelines favour non-invasive respiratory support. Strategies to improve the success rate of non-invasive ventilation in preterm infants include pharmacological treatment of AOP. Among the different pharmacological options, caffeine citrate is the current drug of choice. Caffeine is effective in reducing AOP and mechanical ventilation and enhances extubation success; it decreases the risk of BPD; and is associated with improved cognitive outcome at 2 years of age, and pulmonary function up to 11 years of age. The commonly prescribed dose $\left(20 \mathrm{mg} \cdot \mathrm{kg}^{-1}\right.$ loading dose, $5-10 \mathrm{mg} \cdot \mathrm{kg}^{-1}$ per day maintenance dose) is considered safe and effective. However, to date there is no commonly agreed standardised protocol on the optimal dosing and timing of caffeine therapy. Furthermore, despite the wide pharmacological safety profile of caffeine, the role of therapeutic drug monitoring in caffeine-treated preterm infants is still debated. This state-of-the-art review summarises the current knowledge of caffeine therapy in preterm infants and highlights some of the unresolved questions of AOP. We speculate that with increased understanding of caffeine and its metabolism, a more refined respiratory management of preterm infants is feasible, leading to an overall improvement in patient outcome.

@ERSpublications

Caffeine is the current drug of choice to prevent and treat apnoea of prematurity. There is no agreed protocol on the optimal timing and dosage of caffeine therapy for preterm babies. Data on caffeine metabolism may optimise individualised therapy. http://bit.ly/2LMuJPY

Cite this article as: Moschino L, Zivanovic S, Hartley C, et al. Caffeine in preterm infants: where are we in 2020? ERJ Open Res 2020; 6: 00330-2019 [https://doi.org/10.1183/23120541.00330-2019].

Received: 28 Nov 2019 | Accepted after revision: 4 Dec 2019

Copyright $\odot$ ERS 2020. This article is open access and distributed under the terms of the Creative Commons Attribution Non-Commercial Licence 4.0. 


\section{Background}

Preterm birth represents a significant healthcare burden and is among the leading causes of infant mortality and long-term morbidity [1]. Therefore, the prevention of morbidities related to prematurity is considered a central health priority $[2,3]$. As the number of children surviving extremely preterm birth is likely to continue to rise over the coming years, an increase in children with respiratory complications is expected [2,4], especially those with chronic lung diseases such as bronchopulmonary dysplasia (BPD) [5-7]. To minimise lung injury and illnesses related to prematurity, neonatologists are focusing on non-invasive ventilation techniques from the very first minutes of life [8,9]. However, non-invasive respiratory support is often ineffective, with a high failure rate of up to $50 \%$ in very low birthweight (VLBW) infants $[10,11]$, most commonly due to insufficient respiratory drive. Thus, apnoea is one of the major well-recognised challenges of prematurity, and remains one of the main indications for invasive ventilation [12-14]. Since the 1970s, methylxanthines have been routinely prescribed in preterm infants to prevent apnoea of prematurity (AOP) and reduce the need for invasive ventilatory support [13]. Of the methylxanthines, caffeine is the drug of choice because of its longer half-life, wider therapeutic range, cost-effectiveness and decreased need for drug-level monitoring compared to other methylxanthines, especially theophylline [15].

Caffeine is one of the top five most prescribed treatments in neonatology [16]. Its stimulating effect was originally recognised by the Ethiopians, but it was the Sufis who probably first used it expressly for its pharmacological effects, in the 15th century $[17,18]$. Caffeine is a trimethylated xanthine with a similar molecular structure to adenosine. It acts as a nonspecific inhibitor of two of the four known adenosine receptors, in particular A1 and A2A, located at multiple sites in the brain [19]. The effects of caffeine on the brain, the lung and the cardiovascular system are summarised in figure 1 [12, 18-40]. The dosage used in the largest randomised controlled trial (RCT) conducted to date investigating caffeine in preterm infants, the Caffeine for Apnea of Prematurity (CAP) trial [33], is the most often quoted template for local caffeine therapy protocols. However, despite its frequent use in routine neonatal practice, there are currently no commonly agreed, standardised protocols on caffeine administration, and there is a particular dearth of knowledge regarding the optimal timing and dosage in the most immature preterm infants $(<29$
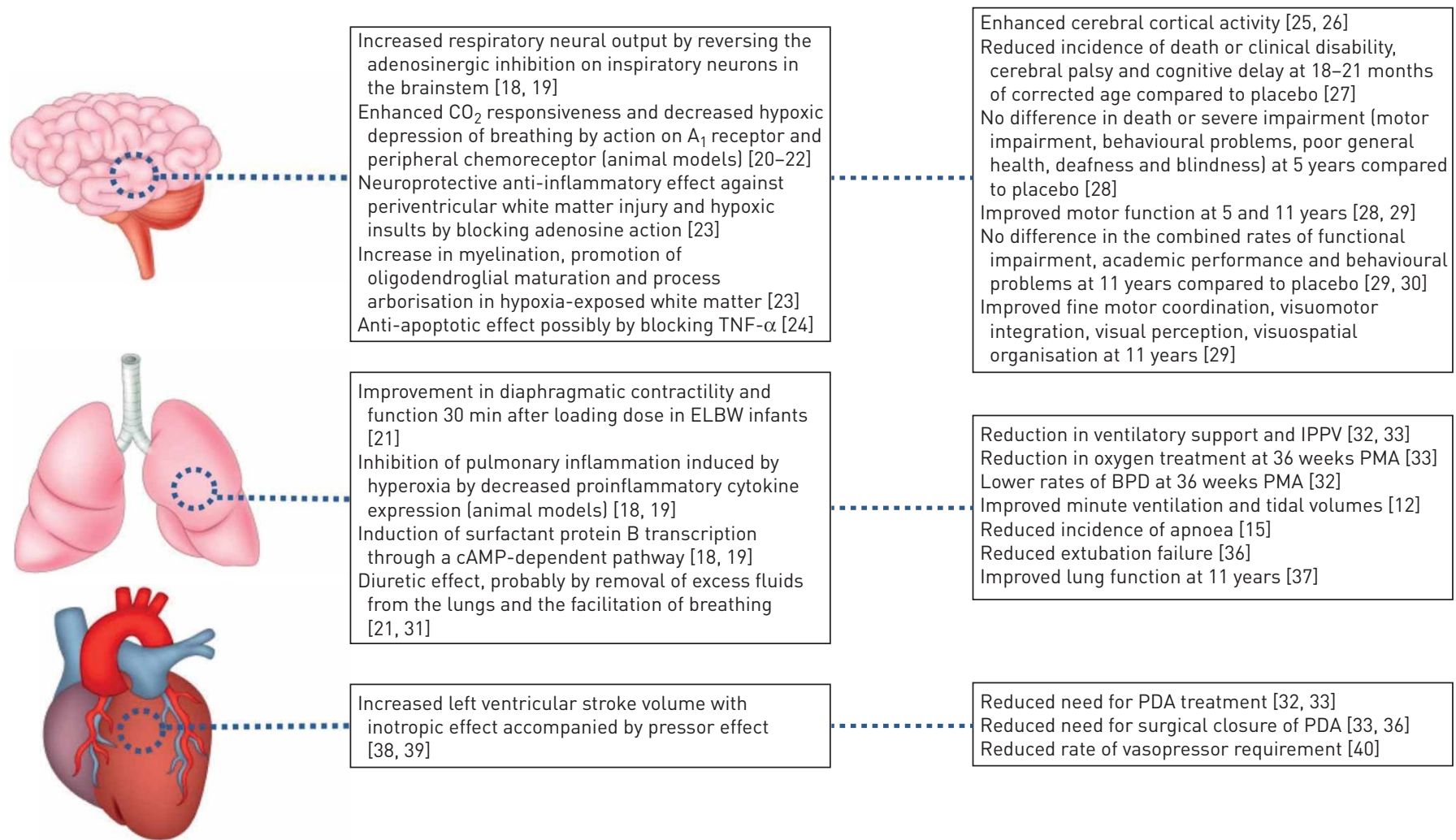

Improvement in diaphragmatic contractility and function 30 min after loading dose in ELBW infants [21]

Inhibition of pulmonary inflammation induced by hyperoxia by decreased proinflammatory cytokine expression (animal models) $[18,19]$

Induction of surfactant protein B transcription through a cAMP-dependent pathway $[18,19]$ Diuretic effect, probably by removal of excess fluids from the lungs and the facilitation of breathing $[21,31]$

Increased left ventricular stroke volume with inotropic effect accompanied by pressor effect $[38,39]$

Reduced need for PDA treatment [32, 33]

Reduction in ventilatory support and IPPV [32, 33]

Reduction in oxygen treatment at 36 weeks PMA [33] Lower rates of BPD at 36 weeks PMA [32]

............ Improved minute ventilation and tidal volumes [12]

Reduced incidence of apnoea [15]

Reduced extubation failure [36]

Improved lung function at 11 years [37]

FIGURE 1 Schematic of the known effects of caffeine citrate during early development on the brain, the lung and the cardiovascular system derived from animal and infant studies. The first column indicates effects on a molecular level, while the second column describes demonstrated caffeine effects in the context of the specific system. $\mathrm{CO}_{2}$ : carbon dioxide; TNF: tumour necrosis factor; ELBW: extremely low birthweight; IPPV: intermittent positive pressure ventilation; PMA: post-menstrual age; BPD: bronchopulmonary dysplasia; PDA: patent ductus arteriosus. 
gestational weeks $(\mathrm{GW})$ ). Additionally, concerns have been raised about potential safety issues and adverse effects, some of which may relate to high caffeine dosages $[19,32]$. These data suggest that the optimal dose and timing of caffeine must still be investigated and be chosen with caution when treating preterm infants. The aim of this review is to present the state-of-the-art of current use of caffeine citrate in preterm infants, with a focus on the known short- and long-term effects of the drug, reported data on timing, dosage and monitoring in order to trigger future research on this hot topic.

\section{The effects of caffeine in preterm infants} Neurological effects

A number of studies have suggested that caffeine intake in preterm infants may have a neuroprotective effect, although researches on animal models have shown contrasting results, probably impacted by the species examined, dose of caffeine used, neurodevelopmental stage at the time of administration and duration of exposure (figure 1) [23, 41-43].

In preterm infants, enhanced cerebral cortical activity, observed as increases in amplitude and periods of continuity on electroencephalography recordings, is seen within $2 \mathrm{~h}$ of administration of caffeine [25, 26], suggesting an effect on neurological function. Furthermore, at 36 weeks post-menstrual age (PMA) infants treated with caffeine therapy had a higher amplitude-integrated electroencephalography score compared to the control group $(p<0.001)$, without an increase in seizure activity [26]. The most comprehensive study to date exploring the long-term effects of caffeine in preterm infants is the CAP trial, whose primary objective was to determine whether survival without neurodevelopmental disability at a corrected age of 18-21 months was altered if AOP was treated with caffeine [33]. 2006 infants (birthweight 500-1250 g) were enrolled and randomly assigned to receive either caffeine $\left(20 \mathrm{mg} \cdot \mathrm{kg}^{-1}\right.$ intravenously as loading dose followed by a maintenance dose of $5 \mathrm{mg} \cdot \mathrm{kg}^{-1}$ per day) or placebo. The caffeine group had a reduced likelihood of death or clinical disability $(40.2 \%$ versus $46.2 \%$; $\mathrm{p}=0.008)$, together with a reduced incidence of cerebral palsy ( $4.4 \%$ versus $7.3 \% ; \mathrm{p}=0.009)$ and of cognitive delay ( $33.8 \%$ versus $38.3 \%$; $\mathrm{p}=0.04)$ [27]. The results of the subsequent follow-up at 5 years of age showed no significant difference between caffeine treatment and placebo in the composite outcome of death or disability ( $21.1 \%$ versus $24.8 \%$; $\mathrm{p}=0.09)$ [28], but a significant improvement of gross motor function in the caffeine group (odds ratio adjusted for centre $0.64, \mathrm{p}=0.006$ ). The long-term follow-up at 11 years of age confirmed previous results of reduced risk of motor impairment ( $19.7 \%$ versus $27.5 \%$; $\mathrm{p}=0.009)$, with no significant difference in the rates of functional impairment ( $31.7 \%$ versus $37.6 \%$; $\mathrm{p}=0.07)$, academic performance and behavioural problems $(10.9 \%$ versus $8.3 \% ; \mathrm{p}=0.22)[29,30]$.

Prolonged treatment with caffeine reduces hypoxaemia events in premature infants [44], the severity and duration of which are probably associated with adverse neurodevelopmental outcomes [45, 46]. Overall neonatal caffeine therapy, at the doses used in the CAP trial, appears to be safe into middle-school age, with no adverse effects on general motor function, intelligence, attention and behaviour.

\section{Caffeine for apnoea, ventilatory support and extubation}

Methylxanthines have been used for $>40$ years in neonatal medicine to reduce the frequency of apnoea, but, apart from the CAP trial, studies and systematic reviews comparing caffeine versus placebo have mainly addressed short-term respiratory outcomes, such as apnoea prophylaxis (one review, two trials), apnoea treatment (one review, three trials), extubation success (one review, two trials) and ventilator support (intermittent positive pressure ventilation (IPPV) and/or mechanical ventilation) (five trials), with a consequent uncertainty of the long-term benefit/risk ratio of this therapy $[15,33,47]$.

The Cochrane review published in 2010 [35], included, in addition to the CAP trial, two studies evaluating the effects of prophylactic caffeine on short-term outcomes. The review concluded against the support of the use of prophylactic caffeine for preterm infants at risk of apnoea, but only one study reported apnoea (as defined by duration $>20 \mathrm{~s}$ with bradycardia $<100 \mathrm{bpm}$ or cyanosis) as an outcome in the results [48].

However, a single-centre RCT [49] on premature infants (birthweight $<1200 \mathrm{~g}$ ) demonstrated a reduction in apnoea episodes (as a breathing pause for $\leqslant 20 \mathrm{~s}$ with bradycardia and/or cyanosis) in the caffeine-treated group compared to placebo ( $15.4 \%$ versus $61.5 \%$, 95\% CI $0.097-0.647$; $\mathrm{p}=0.001$ ), with the more immature infants having the greater benefit of prophylactic caffeine on the incidence and severity of apnoea. The limitations of this study, which was published after the 2010 Cochrane review, are the monocentric setting, the small sample size (26 infants in the treatment group versus 26 in the placebo group) and the unprecise detection of apnoea (daily neonatal intensive care unit reports and monitor downloads). In general, the definition of prophylactic caffeine in terms of hours of life at first administration can be debated, as it is supposed that apnoea events can occur from the first hour of life, and studies comparing caffeine in the delivery room versus placebo to reduce the incidence of apnoea are lacking. 
Another Cochrane review published in 2010 [15] evaluated the effects of methylxanthine treatment on the incidence of apnoea (American Academy of Pediatrics 2003 definition [50]) and included three trials on caffeine. The analysis of the two trials $[51,52]$ on caffeine, without considering the CAP trial, found significantly less treatment failure (relative risk $0.46,95 \%$ CI $0.27-0.78$, number needed to treat 3 ) as defined by $<50 \%$ reduction in apnoea, or use of IPPV, or death during the study period (by 5 and 10 days from starting treatment).

Finally, the last Cochrane review of the series summarised the effects of prophylactic methylxanthine treatment to improve the chances of successful extubation, with failed extubation defined within 1 week of commencing treatment, if unable to wean from IPPV and extubate, or reintubation for IPPV, or need for use of continuous positive airways pressure (CPAP) [36]. Overall analysis of the six included trials showed that methylxanthine treatment results in an absolute reduction of $27 \%$ in the incidence of failed extubation. However, although all trials had the aim of improving the chances of successful extubation, protocols differed considerably, and only two trials compared caffeine versus placebo [33, 53].

The large CAP trial was included in each of the three Cochrane reviews, but did not report on apnoea outcomes and extubation success, although recruited infants received caffeine for any one of the three indications (prophylaxis for apnoea (22\%), treatment of apnoea (40\%) or prophylaxis for extubation (38\%)).

However, the CAP trial clearly demonstrated that caffeine treatment within the first 10 days of life determined a reduction in each of the three levels of respiratory support (need for endotracheal tube, any positive pressure ventilation (PPV), supplemental oxygen) of 1 week compared to placebo $(\mathrm{p}<0.001)$, with no difference according to the indication for starting treatment. Interestingly, the positive results on respiratory support, together with the significantly reduced rate of $\mathrm{BPD}$, surgical closure of patent ductus arteriosus (PDA) and of use of postnatal steroids, explained 55\% of caffeine effect on the primary neurological outcomes at 18-21 months of age (with the most important variable being earlier discontinuation of PPV), suggesting a direct neuroprotective effect of the drug [33].

As a result of these findings, caffeine is the drug of choice to reduce apnoea rates, need for IPPV, ventilatory support, extubation failure and PDA ligation in preterm infants. However, the role of caffeine on longer term clinical outcomes, such as apnoea incidence till 34 corrected gestational weeks, infant respiratory morbidity within the first year of age, need for oxygen treatment after discharge and lung function up until adult age needs to be further investigated in appropriately designed RCTs.

\section{$B P D$ and long-term pulmonary outcomes}

Caffeine is one of the few known drugs proven to reduce the risk of BPD at 36 weeks PMA. However, most of the studies evaluating this outcome have been limited in number, have used different definitions of BPD and have not reported longer-term pulmonary outcomes. The main data stem from the results of the CAP trial. Other studies have compared different timing of caffeine treatment or different doses of the drug, and have been conducted mainly retrospectively.

In the Cochrane review on methylxanthines for extubation [36] two trials, the first comparing caffeine versus placebo [53] and the second comparing caffeine, theophylline and placebo, reported rates of BPD defined as oxygen supplementation at 28 days of life in the first, but undefined in the second. Therefore, conclusions on this outcome could not be performed.

In the CAP trial [33], caffeine use led to a $36 \%$ decrease in BPD at 36 weeks PMA as defined by SHENNAN et al. [54], although the definition of BPD is continuously put into question and debate [55, 56]. Interestingly, the post hoc subgroup analysis of the CAP data showed an influence of postnatal age at onset of caffeine treatment on BPD reduction [34], and these findings were confirmed by subsequent cohort studies (further details in section on Benefits of early caffeine administration) [32, 57]. Encouragingly, the effect of caffeine therapy on BPD in the neonatal period seems to have positive repercussions on later lung function as well, as demonstrated by the results of the follow-up at 11 years in Australian former CAP study participants. In this study, expiratory flows were improved by $0.5 \mathrm{SD}$ in children randomised to caffeine (forced expiratory volume at $1 \mathrm{~s}$ mean $\mathrm{z}$-score -1.00 versus -1.53 , 95\% CI $0.14-0.94$; $\mathrm{p}=0.008$ ), with $11 \%$ versus $28 \%$ with forced vital capacity values below the fifth centile [37]. However, when the respiratory outcomes were adjusted for the higher incidence of BPD in the placebo group, the independent effect of caffeine was lost. As suggested in a comment by JовE [58] after the publishing of these results, caffeine is extremely useful in minimising apnoea of prematurity with associated improved lung and motor function at 11 years of age. Nevertheless, it is not a lung drug per se, as it minimises interventions for respiratory control abnormalities in the very preterm infant that result in lung injury persisting into childhood.

Overall, studies have demonstrated that caffeine is effective in reducing BPD rates, especially when administered in the first 3 days of life (see later). A follow-up of the CAP trial has shown a positive 
long-term effect of caffeine on lung function. However, further trials are needed in order to draw more conclusions on the long-term benefits of caffeine in terms of respiratory outcomes, and to target the appropriate population for early treatment.

\section{Caffeine timing: early versus late}

\section{Benefits of early caffeine administration}

A post hoc subgroup analysis of results from the CAP trial suggested an influence of postnatal age at onset of caffeine treatment on BPD reduction, with a decrease in the rate of BPD by $52 \%$ in those with early treatment (1-3 days of life) in contrast with a reduction of only $23 \%$ if started after day 3 [34]. Since the publication of the results of the CAP trial caffeine has been administered closer and closer to birth, sometimes even in the delivery room [12]. The 2019 European consensus guidelines on the management of neonatal respiratory distress syndrome in preterm infants and the recently published National Institute for Health and Care Excellence recommendations on preterm infants emphasise the role of the timing of caffeine initiation, suggesting that earlier treatment is associated with increased benefit $[59,60]$. Nonetheless, no formal guidance specifying the exact timing of therapy commencement has been provided so far.

A retrospective cohort study on 140 infants (birthweight $<1250 \mathrm{~g}$ ) by PATEL et al. [61] in 2013 demonstrated that early caffeine initiation ( $<3$ days of life) was associated with a reduced rate of death or $\mathrm{BPD}$, decreased requirement of PDA treatment and shorter duration of mechanical ventilation compared to later caffeine initiation ( $\geqslant 3$ days of life). Infants with birthweight $<750 \mathrm{~g}$, considered to be at the highest risk for BPD or death, showed the strongest association between early caffeine initiation and decreased incidence of this combined outcome. These results were confirmed by two retrospective studies conducted in 2014. The first study included 29070 VLBW infants [32], half of whom received early caffeine treatment and were matched on baseline demographics to infants in the late caffeine group. Infants in the early caffeine group had a reduced rate of the composite outcome of death or BPD, less PDA requiring treatment and fewer days of mechanical ventilation. Although infants born at $<24 \mathrm{GW}$ treated with early caffeine showed increased odds of death, this result was attributed to survival bias (need to survive to receive later caffeine), as many very preterm infants die in the first $48 \mathrm{~h}$ [32]. The second study by LoDHA et al. [57] from the Canadian Neonatal Network also showed decreased odds of death or BPD in the group treated with early caffeine ( $<2$ days of life), with most of this effect stemming from the reduction of BPD. In addition, they found a reduced incidence of PDA and duration of mechanical ventilations. Importantly, follow-up of 2108 infants in this study at 18-24 months corrected age demonstrated lower odds of neurodevelopmental impairment in the early caffeine group [62].

Three prospective studies have also suggested benefits of early caffeine administration. A small pilot double-blinded, randomised, placebo-controlled trial conducted in 2015 on 21 infants $(<29 \mathrm{GW})$ randomised to early prophylactic use of caffeine $(<2 \mathrm{~h}$ of age) or to later caffeine initiation (at $12 \mathrm{~h}$ of age), reported improved blood pressure and systemic blood flow (significantly higher superior vena cava flow and right ventricular output) in the early group, and a trend towards reduced rates of intubation by $12 \mathrm{~h}$ of age (27\% versus $70 \%$; $\mathrm{p}=0.08$ ), but no reduction in the number of days of mechanical ventilation [40]. More recently, a prospective cohort study on 986 infants $(\leqslant 32 \mathrm{GW})$ with respiratory distress syndrome demonstrated that early caffeine treatment $(<24 \mathrm{~h}$ after birth) compared to later treatment $(\geqslant 2$ days) was associated with a significantly reduced need for invasive ventilation, total duration of mechanical ventilations and significantly lower odds of intraventricular haemorrhage (IVH) and PDA, but no difference in the incidence of BPD and mortality rates [63]. Finally, in a small cohort randomised study, DekKer et al. [12] demonstrated benefits of caffeine administered in the delivery room on minute volumes and tidal volumes at 7-9 min after birth compared to caffeine given after arrival in the neonatal intensive care unit.

Three systematic reviews and meta-analyses have summarised the results of all the studies published so far comparing early versus late caffeine administration. The first, conducted by PARK et al. [64] in 2015 included VLBW infants (birthweight $<1500 \mathrm{~g})$ treated with early use of caffeine (0-2 days of life) versus late use ( $\geqslant 3$ days of life). This meta-analysis of five studies $[32,34,61,65,66]$ concluded that early caffeine use was associated with a decreased incidence of death, BPD and the composite measure of the two, while the duration of mechanical ventilation was not significantly reduced. The second review and meta-analysis by KUA and LEE [67], published in 2017, selected 14 studies in which early caffeine $(<3$ days of life) was compared with late caffeine, placebo or theophylline. The meta-analysis of the five cohort studies $[34,57,61,65,68]$ comparing early versus late caffeine showed reduced rates of BPD, PDA, PDA requiring surgical intervention, brain injury and duration of mechanical ventilation in the early caffeine group, but an increased rate of death, which was not confirmed by the pooled analysis of two randomised control trials [34, 69]. A more recent systematic review and meta-analysis by PAKvasA et al. [70] has explored the effect of both timing of caffeine initiation and dose of caffeine therapy on clinical outcomes 
(primary: BPD as defined by each specific study or by the need for oxygen at 36 weeks PMA; secondary: death, BPD or death, PDA, necrotising enterocolitis, retinopathy of prematurity, duration of mechanical ventilation and neurodevelopmental impairment). The analysis of the five included observational studies $[32,57,61,66,71]$ demonstrated a decreased risk of BPD with earlier initiation of caffeine $(<3$ days of life), while only one RCT comparing early versus routine use of caffeine was identified, and therefore meta-analysis could not be performed [34].

The clinical benefits of beginning caffeine treatment before 3 days of age has been summarised recently by DoBSON and HunT [72], showing the reduced incidence of BPD (with moderate quality of evidence according to the Grading of Recommendations Assessment, Development and Evaluation system), death or BPD, IVH, necrotising enterocolitis, need for treatment of PDA, retinopathy of prematurity and use of postnatal steroids (all of which with low quality of evidence) with the early treatment.

\section{Contrasting results on early caffeine administration}

A retrospective analysis conducted by PATEL et al. [73] on VLBW infants (birthweight $<1500 \mathrm{~g}$ ) receiving initial CPAP (on day of life 0) compared the effect of early caffeine (day of life 0) versus routine caffeine (day of life 1-6). The results demonstrated no difference in CPAP failure defined as invasive mechanical ventilation or surfactant therapy on day of life $1-6$ (22\% versus $21 \%$, adjusted odds ratio (aOR) 1.05 ), in exposure to a maximal inspiratory oxygen fraction $>0.3$ in the first week of life $(27 \%$ versus $32 \%$, aOR 1.05) and in the total duration of CPAP therapy (median 3 versus 2 days, aOR 1.02). The authors hypothesised that mechanisms influencing CPAP failure might be different from those influencing the risk of BPD or duration of respiratory support.

In a recent single-centre double-blinded placebo-controlled trial [74], preterm infants (23-30 GW) requiring mechanical ventilations in the first five postnatal days were randomised to receive an early caffeine loading dose of $20 \mathrm{mg} \cdot \mathrm{kg}^{-1}$ followed by $5 \mathrm{mg} \cdot \mathrm{kg}^{-1}$ per day or placebo until considered ready for extubation (the control group then received a pre-extubation bolus of caffeine, whereas the intervention group received a pre-extubation bolus of placebo). Caffeine treatment did not reduce age of first successful extubation $(>24 \mathrm{~h})$ nor total duration of mechanical ventilation, incidence of BPD, severe BPD or the composites of BPD or death. Furthermore, a nonsignificant trend towards higher mortality in the early caffeine group led to a cautious decision to stop the trial (22\% versus $12 \%$; $\mathrm{p}=0.22)$. However, one-third of the deaths in the caffeine group occurred after the first successful extubation, when both groups were receiving caffeine. Furthermore, a recent external analysis of the study [75] highlights that, given the early termination of the trial, the differences in prognostic variables for mortality between groups (gender, Apgar score at $5 \mathrm{~min}$ and birthweight) and the imprecision in the estimates of the treatment effect of early caffeine on mortality, no confident conclusions can be determined regarding the effect of early caffeine on mortality.

Currently there are two main ongoing trials exploring the use of early caffeine initiation (data sourced from ClinicalTrials.gov database (https://clinicaltrials.gov)). The first is a double-blind, randomised, placebo-controlled trial evaluating the need for endotracheal intubation within the first $12 \mathrm{~h}$ of life and the cardiac output in neonates born at $<32 \mathrm{GW}$ receiving caffeine either within $2 \mathrm{~h}$ after birth or at $12 \mathrm{~h}$ after birth (clinicaltrials.gov identifier NCT0308647). The second is a randomised, double-blind controlled trial of extremely low birthweight newborns (birthweight $\leqslant 1000 \mathrm{~g}$ and $<28 \mathrm{GW}$ ) aiming to evaluate the cumulative incidence of death and BPD between groups receiving caffeine $\left(20 \mathrm{mg} \cdot \mathrm{kg}^{-1}\right.$ i.v. bolus, then i.v. or by mouth $5 \mathrm{mg} \cdot \mathrm{kg}^{-1}$ daily for 14 days), or placebo (dextrose) within $24 \mathrm{~h}$ of life and then for the subsequent 14 days (clinicaltrials.gov identifier NCT02524249). The results of these trials will be able to shed further light on the best timing for caffeine administration in order to potentially reduce these shortand long-term outcomes.

Table 1 summarises the studies conducted to date in this area. Overall, caffeine administered within the first 3 days of life seems to provide a reduction in BPD rates, PDA and IVH, but does not reduce the risk of CPAP and extubation failure. In addition, there are still contrasting results of the effect of early caffeine initiation on duration of mechanical ventilation and death. There is an urgent need for RCTs addressing this issue, as most results stem from retrospective studies or trials with small sample sizes.

\section{Caffeine dosage: high versus low/standard dose}

Similar to timing of caffeine treatment initiation, there is still uncertainty regarding the optimal dose of caffeine in preterm infants. In 1977 ARANDA et al. [76] administered $20 \mathrm{mg} \cdot \mathrm{kg}^{-1}$ i.v. caffeine citrate to 18 preterm infants followed by 5 or $10 \mathrm{mg} \cdot \mathrm{kg}^{-1}$ once or twice daily, demonstrating a reduction in mean frequency of apnoeic spells from 13.6 to 2.1 per day $(p<0.01)$. Subsequent studies investigating the relationship of dose and plasma concentrations of caffeine indicated a rapid rise in minute ventilation followed by a plateau in the ventilatory response with increasing doses of the drug [77]. These 
TABLE 1 Summary of retrospective studies, post hoc analyses, randomised controlled trials (RCTs) and systematic reviews and meta-analyses comparing early versus late caffeine treatment in preterm infants

\begin{tabular}{|c|c|c|c|c|c|}
\hline \multirow{2}{*}{$\begin{array}{l}\text { First author, year } \\
\text { [ref.] }\end{array}$} & \multirow{2}{*}{$\begin{array}{c}\text { Study characteristics, regimen, } \\
\text { limitations }\end{array}$} & \multicolumn{2}{|c|}{ Patient characteristics } & \multicolumn{2}{|c|}{ Main significant findings } \\
\hline & & Early caffeine & Late caffeine & Benefits of early caffeine & $\begin{array}{l}\text { Drawbacks or no effect of } \\
\text { early caffeine }\end{array}$ \\
\hline Davis, 2010 [34] & $\begin{array}{c}\text { Post hoc subgroup analysis of the CAP } \\
\text { trial } \\
\text { Caffeine citrate } \\
20 \mathrm{mg} \cdot \mathrm{kg}^{-1} \text { load } \leqslant 3 \text { DoL versus }>3 \mathrm{DoL} \\
\text { Post hoc analysis for treatment indication, } \\
\text { not as primary outcome }\end{array}$ & & & $\begin{array}{l}\text { Larger reduction in days of respiratory } \\
\text { support ( } \mathrm{p}=0.02) \\
\text { Lower PMA at time of discontinuing PPV } \\
\text { (mean difference } 1.35 \text { weeks }(0.90-1.81) \\
\text { versus } 0.55 \text { weeks }(-0.11-0.99) \text { ) }\end{array}$ & \\
\hline $\begin{array}{l}\text { ABBASI, } 2010 \\
\text { (abstract) [65] }\end{array}$ & $\begin{array}{c}\text { Retrospective cohort study } \\
\text { Early caffeine }(0-2 \text { DoL) versus late } \\
\text { caffeine }(\geqslant 3 \text { DoL) } \\
\text { Retrospective, many data not available; } \\
\text { Newcastle-Ottawa score for risk of } \\
\text { bias } 4\end{array}$ & $\begin{array}{l}166 \text { case/control } \\
\text { pairs, BW } 500-1250 \mathrm{~g}\end{array}$ & & Reduced odds of IVH (OR 0.37) & \\
\hline Patel, 2013 [61] & $\begin{array}{c}\text { Retrospective cohort study } \\
\text { Caffeine initial dose }<3 \text { DoL versus } \\
\geqslant 3 \text { DoL } \\
\text { Retrospective, single-centre; indication } \\
\text { for caffeine therapy unknown; no } \\
\text { protocol on caffeine use }\end{array}$ & $\begin{array}{c}83 \text { neonates } \\
\text { BW } 940(730-1100) \mathrm{g} \\
\text { GA } 27.3(25.6-28.7) \\
\text { weeks }\end{array}$ & $\begin{array}{c}57 \text { neonates } \\
\text { BW } 910 \text { (715-1035) } \\
\mathrm{g} \\
\text { GA 26.6 (25.3-27.7) R } \\
\text { weeks }\end{array}$ & $\begin{array}{c}\text { Decreased incidence of death or BPD } \\
(25.3 \% \text { versus } 52.6 \% \text { ) by a reduced rate } \\
\text { of BPD (23.6\% versus } 50.9 \%) \\
\text { Reduced need for treatment of PDA ( } 10.4 \% \\
\text { versus } 36.4 \%)\end{array}$ & \\
\hline $\begin{array}{l}\text { SAEIDI, } 2014 \text { (abstract) } \\
\text { [69] }\end{array}$ & $\begin{array}{c}\mathrm{RCT} \\
\text { Caffeine citrate } 20 \mathrm{mg} \cdot \mathrm{kg}^{-1} \text { load within } \\
\text { first } 3 \text { DoL versus } \geqslant 3 \text { DoL } \\
\text { Single-centre; small sample size; many } \\
\text { data not available }\end{array}$ & $\begin{array}{c}16 \text { neonates } \\
\text { BW } 1123 \pm 244 \mathrm{~g} \\
\text { GA } 29.5 \pm 2.0 \text { weeks (BW } \\
\text { and GA for all } 36 \\
\text { included infants) }\end{array}$ & 20 neonates & $\begin{array}{l}\text { Marginal reduction in BPD and } \\
\text { significant reduction in apnoea }\end{array}$ & \\
\hline DoBson, 2014 [32] & $\begin{array}{l}\text { Retrospective analysis } \\
\text { Caffeine initial dose }<3 \text { DoL versus } \\
\qquad 3 \text { DoL } \\
\text { Retrospective; variable indications for } \\
\text { early caffeine use among centres } \\
\text { (hypothetically: apnoea, } \\
\text { prophylactically, weaning from MV and } \\
\text { reduction in BPD); possible changes in } \\
\text { clinical practice during the study } \\
\text { period }\end{array}$ & $\begin{array}{c}14535 \text { neonates } \\
\text { BW } 1055 \text { (630-1447) g } \\
\text { GA } 28.1(25.0-31.0) \\
\text { weeks }\end{array}$ & $\begin{array}{c}14535 \text { neonates } \\
\text { BW } 1054(590-1460) \\
g \\
\text { GA } 28(24.0-32.0) \\
\text { weeks }\end{array}$ & $\begin{array}{c}\text { Reduced risk of BPD by } 7.6 \% \text { ( } 23.1 \% \\
\text { versus } 30.7 \%) ; \\
\text { Reduction in MV days at } 36 \text { weeks PMA } \\
\text { (median } 11 \text { versus } 17 \text { days) } \\
\text { Reduction in PDA requiring treatment } \\
\text { (12.3\% versus } 19 \% \text { ) }\end{array}$ & $\begin{array}{c}\text { Higher odds of death IOR } 1.23 \text {, } \\
95 \% \mathrm{Cl} 1.05-1.43 ; 4.5 \% \text { versus } \\
3.7 \% \text { ) }\end{array}$ \\
\hline
\end{tabular}


TABLE 1 Continued

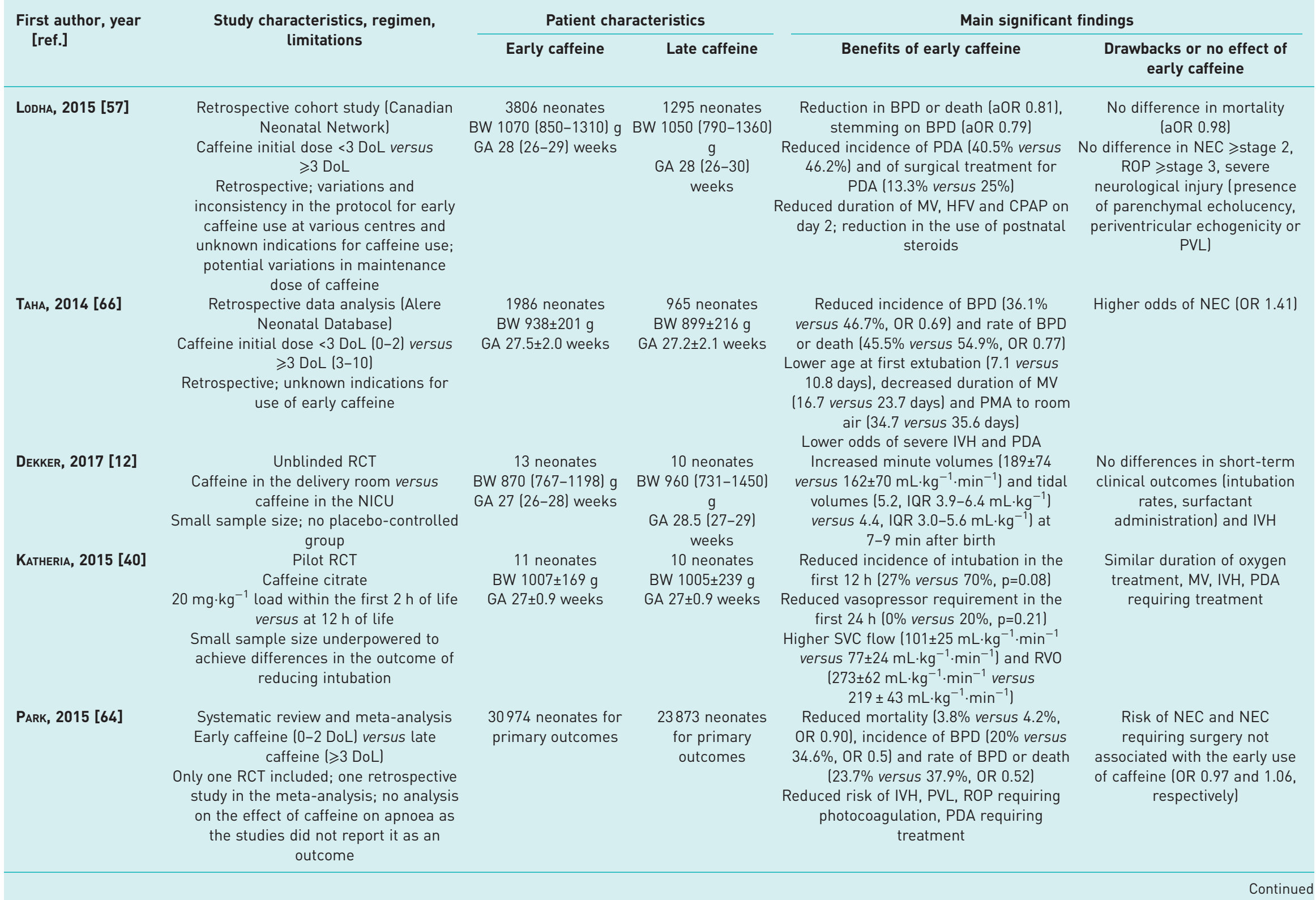




\begin{tabular}{|c|c|c|c|c|c|}
\hline \multirow{2}{*}{$\begin{array}{l}\text { First author, year } \\
\text { [ref.] }\end{array}$} & \multirow{2}{*}{$\begin{array}{c}\text { Study characteristics, regimen, } \\
\text { limitations }\end{array}$} & \multicolumn{2}{|c|}{ Patient characteristics } & \multicolumn{2}{|c|}{ Main significant findings } \\
\hline & & Early caffeine & Late caffeine & Benefits of early caffeine & $\begin{array}{c}\text { Drawbacks or no effect of } \\
\text { early caffeine }\end{array}$ \\
\hline KuA, 2017 [67] & $\begin{array}{c}\text { Systematic review and meta-analysis } \\
\text { Early caffeine (initiated }<3 \text { DoL) in } \\
\text { preterm infants } \\
\text { No information on the indications for } \\
\text { early versus late caffeine treatment } \\
\text { from the studies; most of the RCTs } \\
\text { had small sample size }\end{array}$ & & & $\begin{array}{l}\text { Meta-analysis of cohort studies and } \\
\text { RCTs: } \\
\text { - Reduction of BPD } 20-33 \% \\
\text { - 29\% reduction in the incidence of PDA } \\
\text { (cohort studies) } \\
-59 \% \text { decrease in the need for surgical } \\
\text { closure of PDA (cohort studies) } \\
\text { - Shorter duration of MV (WMD } \\
-7.5 \text { days) }\end{array}$ & $\begin{array}{c}\text { Increase in absolute risk of } \\
\text { mortality with early caffeine } \\
\text { therapy ( } 4.7 \% \text { versus } 3.9 \%) \text {. } \\
\text { No difference in rates of NEC, } \\
\text { need for surfactant, home } \\
\text { oxygen }\end{array}$ \\
\hline $\begin{array}{l}\text { BoRSZEWSKA-KoRNACKA, } \\
2017 \text { [63] }\end{array}$ & $\begin{array}{l}\text { Prospective cohort study } \\
\text { Early (initial dose on DoL 1) } \\
\text { and late (initial dose on DoL } \geqslant 2 \text { ) caffeine } \\
\text { therapy } \\
\text { Possible differences in local practices } \\
\text { between centres; no randomisation }\end{array}$ & $\begin{array}{c}143 \text { neonates } \\
\text { BW } 1130(895-1450) \mathrm{g} \\
\text { GA } 29(27-30) \text { weeks }\end{array}$ & $\begin{array}{c}143 \text { neonates } \\
\text { BW } 1100 \\
(850-1485) \mathrm{g} \\
\text { GA } 29(27-30) \text { weeks }\end{array}$ & $\begin{array}{c}\text { Significant lower incidence of PDA (25\% } \\
\text { versus } 37 \% \text {, OR } 0.56 \text { ) } \\
\text { Reduced incidence of IVH ( } 42.1 \% \text { versus } \\
60.1 \%, \text { OR } 0.48 \text { ) } \\
\text { Reduced duration of MV (IQR } 0-4 \text { versus } \\
\text { IQR 1-15.9) }\end{array}$ & $\begin{array}{c}\text { No statistically significant } \\
\text { difference in the incidence of } \\
\text { BPD (36.4\% versus } 45.8 \% \text {, } \\
\text { p=0.31) and mortality rates } \\
\text { (8.6\% versus } 8.5 \% \text {, } \\
\text { nonsignificiant) }\end{array}$ \\
\hline Patel, 2017 [73] & $\begin{array}{l}\text { Multicentre, observational cohort study } \\
\text { Early caffeine (initiation on DoL 0) versus } \\
\text { late caffeine (initiation on DoL 1-6) } \\
\text { No adjustment for factors possibly } \\
\text { associated with doctor's decision to } \\
\text { start caffeine; highly selected infants } \\
\text { excluding those with need of } \\
\text { surfactant or lower Apgar score }\end{array}$ & $\begin{array}{c}4528 \text { neonates } \\
\text { BW <1500 g } \\
\text { GA } 29(28-30) \text { weeks }\end{array}$ & $\begin{array}{c}6605 \text { neonates } \\
\text { BW }<1500 \mathrm{~g} \\
\text { GA } 30(29-31) \\
\text { weeks }\end{array}$ & & $\begin{array}{c}\text { Similar incidence of CPAP } \\
\text { failure (22\% versus 21\%, OR } \\
1.05 \text { ) } \\
\text { No difference in exposure to a } \\
\text { max } F_{\mathrm{iO}_{2}}>0.3(27 \% \text { versus } \\
32 \%, \text { OR } 1.05 \text { ) } \\
\text { No difference in duration of } \\
\text { CPAP therapy (3 versus } 2 \text { days, } \\
\text { OR 1.02) }\end{array}$ \\
\hline
\end{tabular}

CAP: Caffeine for Apnoea of Prematurity; DoL: day of life; PMA: post-menstrual age; PPV: positive pressure ventilation; BW: birthweight; IVH: intraventricular haemorrhage; GA: gestational age; BPD: bronchopulmonary dysplasia; PDA: patent ductus arteriosus; MV: mechanical ventilation; aOR: adjusted odds ratio; HFV: high-frequency ventilation; CPAP: continuous positive airway pressure; NEC: necrotising enterocolitis; ROP: retinopathy of prematurity; PVL: periventricular leukomalacia; NICU: neonatal intensive care unit; IQR: interquartile range; SVC: superior vena cava; RVO: right ventricular output; WMD: weighted mean difference; $F_{\mathrm{iO}_{2}}$ : fraction of inhaled oxygen. 
observations, coupled with the unusual pharmacokinetic profile of caffeine, described later, led to the standard dose regimen that is widely used today: an i.v. loading dose of $20 \mathrm{mg} \cdot \mathrm{kg}^{-1}$ of caffeine citrate $\left(10 \mathrm{mg} \cdot \mathrm{kg}^{-1}\right.$ of caffeine base) followed by a maintenance dose of $5-10 \mathrm{mg} \cdot \mathrm{kg}^{-1}$ per day started $24 \mathrm{~h}$ after the loading dose. This regimen was the one adopted in the CAP trial and recommended by the US Food and Drug Administration to treat apnoea of prematurity $[78,79]$.

In 1992 an RCT was published comparing two different regimens of caffeine with theophylline in a group of preterm infants (gestational age $<31 \mathrm{GW}$ ), showing a loading dose of $50 \mathrm{mg} \cdot \mathrm{kg}^{-1}$ caffeine citrate to be more effective in reducing apnoeic episodes within $8 \mathrm{~h}$ after administration than a loading dose of $25 \mathrm{mg} \cdot \mathrm{kg}^{-1}$, with no particular side-effects [80]. In 2003, a randomised double-blind clinical trial of three dosing regimens of caffeine citrate for periextubation management of ventilated preterm infants $(<32 \mathrm{GW})$ demonstrated that the higher daily maintenance doses (of 15 and $30 \mathrm{mg} \cdot \mathrm{kg}^{-1}$ per day) significantly reduced documented apnoea, but with no statistically significant difference in the incidence of extubation failure [81]. However, in a subsequent multicentre double-blind RCT the same authors found that a dose of $20 \mathrm{mg} \cdot \mathrm{kg}^{-1}$ given $24 \mathrm{~h}$ before a planned extubation or within $6 \mathrm{~h}$ of an unplanned extubation in infants $<30 \mathrm{GW}$ reduced the rate of extubation failure within $48 \mathrm{~h}$ compared to a low maintenance dose of $5 \mathrm{mg} \cdot \mathrm{kg}^{-1}$, with no effect on infant mortality and major neonatal morbidities in the first year of life. Furthermore, a significant reduction in duration of mechanical ventilations was shown in infants $<28 \mathrm{GW}$ receiving the high dose regimen [82]. Confirming these results, an RCT demonstrated that the use of high loading and maintenance doses of caffeine citrate (loading/maintenance doses of 40/20 versus 20/ $10 \mathrm{mg} \cdot \mathrm{kg}^{-1}$ ) was associated with a significant decrease in extubation failure in preterm infants $<32 \mathrm{GW}$ and a decreased frequency of apnoea, with no differences in the incidence of major disabilities, but with more episodes of tachycardia [83].

Three systematic reviews and meta-analyses have summarised the results of RCTs assessing the efficacy and safety of higher dosage regimens of caffeine in preterm infants. A review by VLIEGENTHART et al. [84] identified six RCTs ( 620 patients, $<32 \mathrm{GW}$ ) with considerable variation in loading and maintenance doses, as well as duration of therapy between allocation arms. The meta-analysis of data showed a potential benefit of a higher caffeine dosing regimen on the combined outcome of death or BPD and on BPD alone at 36 weeks PMA when therapy was given for $>14$ days. Meta-analysis for apnoea frequency could not be performed due to variation in definitions. One study reported an increased risk of cerebellar haemorrhage $(\mathrm{CBH})$ with higher doses of caffeine [85]. However, this study was powered only to detect differences in the primary outcome of microstructural brain development at term-equivalent age, and long-term neurodevelopment is a better outcome compared to single cerebellar lesions or other short-term neurological effects. In addition, a recent retrospective study of 218 preterm infants $<28 \mathrm{GW}$ divided into two groups to receive either a median loading dose of the drug of $80 \mathrm{mg} \cdot \mathrm{kg}^{-1}$ or of $20 \mathrm{mg} \cdot \mathrm{kg}^{-1}$ within the first $36 \mathrm{~h}$ of age, has shown no difference in the incidence of neonatal morbidities, including $\mathrm{CBH}$, between the two groups (2.5\% versus 1.7\%) [86]. A second review and meta-analysis published by BRATTSTRÖM et al. [87] comparing a high versus low dose of caffeine [88, 90-] identified six RCTs (total of 816 infants, $<32 \mathrm{GW}$ ), with loading and maintenance doses varying between 20 and $80 \mathrm{mg} \cdot \mathrm{kg}^{-1}$ per day and 3-20 mg. $\mathrm{kg}^{-1}$ per day, respectively, and diverse times of starting treatment. The use of high dose had no impact on mortality, but showed a reduction of BPD [91] with a risk ratio of $0.76(0.60-0.96)$, very similar to Vliegenthart's calculation [92]. Furthermore, it resulted in fewer cases of extubation failure and apnoea and a shorter duration of mechanical ventilations, despite higher rates of tachycardia.

The last systematic review and meta-analysis by PAKVASA et al. [70] included three RCTs comparing high-dose caffeine with the standard dose $[82,83,85]$, showing a decreased risk of BPD in the first group. In addition, the meta-analysis of three studies demonstrated an increased efficacy of high-dose caffeine in reducing AOP [81-83].

One additional review and meta-analysis published in 2018 [92] has evaluated efficacy and safety of different maintenance doses of caffeine citrate to treat AOP. The review included 13 RCTs, of which five were written in English. It concluded that the high-dose group (maintenance doses of $10-20 \mathrm{mg} \cdot \mathrm{kg}^{-1}$ ) exhibited greater effective treatment rate (defined as successful extubation within $72 \mathrm{~h}$ after treatment onset, fewer than three apnoea episodes per day, and no significant abnormalities in respiratory rhythm), success rate for ventilator removal, lower extubation failure rate, frequency of apnoea, apnoea duration and rate of $\mathrm{BPD}$.

The evidence so far (summarised in table 2) suggests that higher doses of caffeine treatment may be more effective in reducing apnoea rates and extubation failure, as well as BPD at 36 weeks PMA. However, future RCTs of high versus low/standard dose of caffeine with larger sample sizes are needed to ameliorate allocation concealment and outcome reporting. Importantly, lack of data on long-term outcomes and safety limits the use of caffeine regimens other than those used in the CAP trial in standard neonatal care. 
TABLE 2 Summary of retrospective studies, post hoc analyses, randomised controlled trials (RCTs) and systematic reviews and meta-analyses comparing high versus low/standard doses of caffeine citrate in preterm infants

\begin{tabular}{|c|c|c|c|c|c|}
\hline \multirow{2}{*}{$\begin{array}{l}\text { First author, } \\
\text { year [ref.] }\end{array}$} & \multirow{2}{*}{$\begin{array}{l}\text { Study characteristics } \\
\text { Patient characteristics } \\
\text { Limitations }\end{array}$} & \multicolumn{2}{|c|}{ Regimen } & \multicolumn{2}{|c|}{ Main significant findings } \\
\hline & & High caffeine dose & $\begin{array}{l}\text { Standard/low } \\
\text { caffeine dose }\end{array}$ & Benefits of high caffeine dose & $\begin{array}{l}\text { Drawbacks or no effects of high } \\
\text { caffeine dose }\end{array}$ \\
\hline $\begin{array}{l}\text { ROMAGNOLI, } \\
1992 \text { [88] }\end{array}$ & $\begin{array}{c}\text { Single-centre RCT } \\
37 \text { total neonates, } 14 \text { (controls) versus } 13 \\
\text { versus } 10 \text { neonates, born <32 GW } \\
\text { Single centre; small sample size; unclear } \\
\text { risk of most biases with incomplete } \\
\text { outcome data }\end{array}$ & $\begin{array}{l}\text { Group I: } \\
\text { LD } 10 \mathrm{mg} \cdot \mathrm{kg}^{-1} \\
\text { MD } 5 \mathrm{mg} \cdot \mathrm{kg}^{-1}\end{array}$ & $\begin{array}{c}\text { Group II: } \\
\text { LD } 10 \mathrm{mg} \cdot \mathrm{kg}^{-1} ; \\
\text { MD } 2.5 \mathrm{mg} \cdot \mathrm{kg}^{-1}\end{array}$ & $\begin{array}{l}\text { Decrease in the number of apnoeic } \\
\text { spells in both treated groups } \\
\text { compared with a control group } \\
\qquad(p<0.01)\end{array}$ & $\begin{array}{c}\text { Significantly lower frequency of } \\
\text { side-effects such as tachycardia } \\
(p<0.001) \text { and gastrointestinal } \\
\text { intolerance in the low-dose group } \\
\text { (nonsignificant) }\end{array}$ \\
\hline $\begin{array}{l}\text { SCANLON, } 1992 \\
\text { [80] }\end{array}$ & $\begin{array}{c}\text { Single-centre RCT } \\
44 \text { total neonates, } 14 \text { versus } 16 \text { neonates (14 } \\
\text { infants treated with theophylline), born } \\
<31 \mathrm{GW} \text {, with frequent apnoeic attacks } \\
(\geqslant 10 \text { in } 8 \mathrm{~h} \text { or } 4 \text { in } 1 \mathrm{~h}] \\
\text { Single centre; small sample size; unclear } \\
\text { risk of most biases with incomplete } \\
\text { outcome data }\end{array}$ & $\begin{array}{l}\text { LD } 50 \mathrm{mg} \cdot \mathrm{kg}^{-1} \\
\text { MD } 12 \mathrm{mg} \cdot \mathrm{kg}^{-1}\end{array}$ & $\begin{array}{l}\text { LD } 25 \mathrm{mg} \cdot \mathrm{kg}^{-1} \\
\text { MD } 6 \mathrm{mg} \cdot \mathrm{kg}^{-1}\end{array}$ & $\begin{array}{l}\text { Number of apnoea events } \cdot \text { day }{ }^{-1} \\
\text { reduced by } 1 / 3 \text { within } 24 \mathrm{~h} \text { by } \\
\text { standard dose treatment versus a } \\
\text { reduction by }>50 \% \text { by the higher } \\
\text { dose treatment within the same } \\
\text { time period }\end{array}$ & \\
\hline $\begin{array}{l}\text { STEER, } 2003 \\
{[81]}\end{array}$ & $\begin{array}{c}\text { Single-centre } \mathrm{RCT} \\
45 \text { versus } 40 \text { versus } 42 \text { neonates }<32 \mathrm{GW} \\
\text { ventilated for }>48 \mathrm{~h} \\
\text { Single centre; small sample size }\end{array}$ & $\begin{array}{l}\text { High dose: } \\
\text { LD } 60 \mathrm{mg} \cdot \mathrm{kg}^{-1} ; \\
\text { MD } 30 \mathrm{mg} \cdot \mathrm{kg}^{-1} \\
\text { Moderate dose: } \\
\text { LD } 30 \mathrm{mg} \cdot \mathrm{kg}^{-1} ; \\
\text { MD } 15 \mathrm{mg} \cdot \mathrm{kg}^{-1}\end{array}$ & $\begin{array}{l}\text { LD } 6 \mathrm{mg} \cdot \mathrm{kg}^{-1} \\
\text { MD } 3 \mathrm{mg} \cdot \mathrm{kg}^{-1}\end{array}$ & $\begin{array}{l}\text { Reduction in documented apnoea } \\
\text { episodes }(p<0.02) \text {; } \\
\text { Trend to decrease in failure of } \\
\text { extubation in the two highest dose } \\
\text { groups }(24 \% \text { versus } 25 \% \text { versus } \\
\qquad 45 \%, p=0.06)\end{array}$ & \\
\hline $\begin{array}{l}\text { STEER, } 2004 \\
{[82]}\end{array}$ & 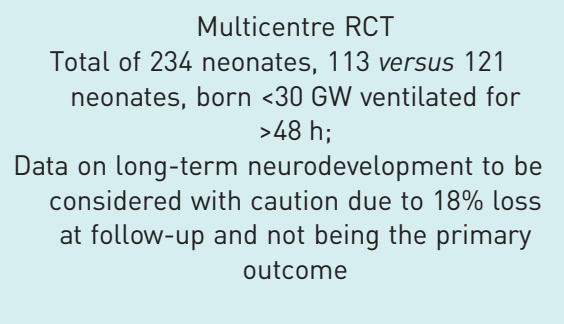 & $\begin{array}{l}\text { MD } 20 \mathrm{mg} \cdot \mathrm{kg}^{-1} \\
\text { before a planned } \\
\text { extubation or } 6 \mathrm{~h} \\
\text { within an unplanned } \\
\quad \text { extubation }\end{array}$ & $\begin{array}{l}\text { MD } 5 \mathrm{mg} \cdot \mathrm{kg}^{-1} \text { before } \\
\text { a planned extubation } \\
\text { or } 6 \mathrm{~h} \text { within an } \\
\text { unplanned extubation }\end{array}$ & $\begin{array}{c}\text { Reduced rate of extubation failure } \\
\text { (15.0\% versus } 29.8 \%, \text { RR } 0.51 ; \\
\text { NNT 7) } \\
\text { Reduction in documented apnoea } \\
\text { episodes ( } 4 \text { (1-12) versus } 7 \text { (2-22), } \\
\text { p<0.01) } \\
\text { ignificant difference in duration of } \\
\text { MV in infants }<28 \mathrm{GW} \text { (mean } \\
14.4 \text { days versus } 22.1 \text { days, } \mathrm{p}=0.01)\end{array}$ & $\begin{array}{l}\text { No difference in mortality, major } \\
\text { morbidities, severe disability }\end{array}$ \\
\hline $\begin{array}{l}\text { GrAY, } 2011 \\
\text { [89] }\end{array}$ & $\begin{array}{c}\text { Multicentre RCT } \\
\text { Total of } 287 \text { neonates, } 120 \text { versus } 126 \\
\text { neonates, born }<30 \mathrm{GW} \\
\text { Some incomplete outcome data (e.g. age at } \\
\text { starting treatment) }\end{array}$ & $\begin{array}{l}\text { LD } 80 \mathrm{mg} \cdot \mathrm{kg}^{-1} \\
\text { MD } 20 \mathrm{mg} \cdot \mathrm{kg}^{-1}\end{array}$ & $\begin{array}{l}\text { LD } 20 \mathrm{mg} \cdot \mathrm{kg}^{-1} \\
\text { MD } 5 \mathrm{mg} \cdot \mathrm{kg}^{-1}\end{array}$ & 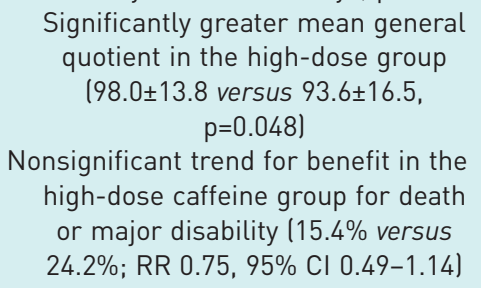 & $\begin{array}{c}\text { No difference in temperament and } \\
\text { behaviour }\end{array}$ \\
\hline
\end{tabular}


TABLE 2 Continued

\begin{tabular}{|c|c|c|c|c|c|}
\hline \multirow{2}{*}{$\begin{array}{l}\text { First author, } \\
\text { year [ref.] }\end{array}$} & \multirow{2}{*}{$\begin{array}{c}\text { Study characteristics } \\
\text { Patient characteristics } \\
\text { Limitations }\end{array}$} & \multicolumn{2}{|c|}{ Regimen } & \multicolumn{2}{|c|}{ Main significant findings } \\
\hline & & High caffeine dose & $\begin{array}{l}\text { Standard/low } \\
\text { caffeine dose }\end{array}$ & Benefits of high caffeine dose & $\begin{array}{l}\text { Drawbacks or no effects of high } \\
\text { caffeine dose }\end{array}$ \\
\hline $\begin{array}{l}\text { МонаммеD, } \\
2015 \text { [83] }\end{array}$ & $\begin{array}{c}\text { Single-centre RCT } \\
60 \text { versus } 60 \text { neonates, born }<32 \mathrm{GW} \\
\text { Single centre; small sample size }\end{array}$ & $\begin{array}{l}\text { LD } 40 \mathrm{mg} \cdot \mathrm{kg}^{-1} \\
\text { MD } 20 \mathrm{mg} \cdot \mathrm{kg}^{-1}\end{array}$ & $\begin{array}{l}\text { LD } 20 \mathrm{mg} \cdot \mathrm{kg}^{-1} \\
\text { MD } 10 \mathrm{mg} \cdot \mathrm{kg}^{-1}\end{array}$ & $\begin{array}{l}\text { Reduction in extubation failure } \\
\qquad(p<0.05) \\
\text { Reduction in frequency of apnoea } \\
(p<0.001)\end{array}$ & $\begin{array}{l}\text { Significant increase in episodes of } \\
\text { tachycardia }(p<0.05) \\
\text { No difference in the incidence of BPD } \\
\text { No difference in the incidence of ROP, } \\
\text { IVH, PVL or LOS }\end{array}$ \\
\hline $\begin{array}{l}\text { McPherson, } \\
2015[85]\end{array}$ & $\begin{array}{c}\text { Single-centre RCT } \\
\text { Total of } 74 \text { neonates, } 37 \text { versus } 37 \text { neonates, } \\
\text { born } \leqslant 30 \mathrm{GW} \\
\text { Pilot study with small sample size only } \\
\text { powered to detect differences in the } \\
\text { primary outcome of microstructural } \\
\text { brain development at term-equivalent } \\
\text { age }\end{array}$ & $\begin{array}{l}\text { LD } 80 \mathrm{mg} \cdot \mathrm{kg}^{-1} \text { over a } \\
\text { 36-h period }(40-20- \\
\text { 10); MD } 10 \mathrm{mg} \cdot \mathrm{kg}^{-1}\end{array}$ & $\begin{array}{l}\text { LD } 30 \mathrm{mg} \cdot \mathrm{kg}^{-1} \text { over a } \\
\text { 36-h period }(20-10) ; \\
\text { MD } 10 \mathrm{mg} \cdot \mathrm{kg}^{-1}\end{array}$ & & $\begin{array}{c}\text { Increased incidence of cerebellar } \\
\text { haemorrhage in the high-dose } \\
\text { group ( } 36 \% \text { versus } 10 \%, p=0.03), \\
\text { more deviant neurological signs } \\
(p=0.04) \text { at term-equivalent age } \\
\text { No differences in diffusion measures } \\
\text { at term-equivalent age and } \\
\text { developmental outcomes at } 2 \text { years }\end{array}$ \\
\hline $\begin{array}{l}\text { ZHAO, } 2016 \\
{[90]}\end{array}$ & $\begin{array}{c}\text { Single-centre RCT } \\
164 \text { total infants, } 82 \text { versus } 82 \text { neonates, } \\
\text { born }<32 \mathrm{GW} \\
\text { Single-centre; possible selection, detection } \\
\text { and reporting biases }\end{array}$ & $\begin{array}{l}\text { LD } 20 \mathrm{mg} \cdot \mathrm{kg}^{-1} \\
\text { MD } 15 \mathrm{mg} \cdot \mathrm{kg}^{-1}\end{array}$ & $\begin{array}{l}\text { LD } 20 \mathrm{mg} \cdot \mathrm{kg}^{-1} \text {; } \\
\text { MD } 5 \mathrm{mg} \cdot \mathrm{kg}^{-1}\end{array}$ & $\begin{array}{l}\text { Reduction in the frequency of } \\
\text { apnoea ( } 10 \text { versus } 18, p=0.009) \\
\text { Higher success rate of ventilator } \\
\text { removal }(85 \% \text { versus } 70 \%, p=0.015 \text { ) }\end{array}$ & $\begin{array}{l}\text { No significant difference in death } \\
\text { during hospitalisation, CLD and } \\
\text { duration of hospital stay } \\
\text { No significant difference in } \\
\text { tachycardia, irritability, difficulty in } \\
\text { feeding, hyperglycaemia, } \\
\text { hypertension, digestive disorders } \\
\text { and electrolyte disturbances }\end{array}$ \\
\hline $\begin{array}{r}\text { VLIEGENTHART, } \\
2018[84]\end{array}$ & $\begin{array}{c}\text { Systematic review and meta-analysis } \\
\text { including } 6 \text { RCTs with a total of } 620 \\
\text { preterm infants; GA } \leqslant 32 \text { GW } \\
\text { Overall quality of the outcome measures } \\
\text { (GRADE) considered low to very low due } \\
\text { to imprecision and inconstancy of the } \\
\text { effect estimates; small sample sizes of } \\
\text { the included studies }\end{array}$ & $\begin{array}{l}\text { LD } 10-80 \mathrm{mg} \cdot \mathrm{kg}^{-1} \\
\text { MD } 5-30 \mathrm{mg} \cdot \mathrm{kg}^{-1}\end{array}$ & $\begin{array}{l}\text { LD 6-30 mg } \cdot \mathrm{kg}^{-1} \\
\text { MD } 2.5-20 \mathrm{mg} \cdot \mathrm{kg}^{-1}\end{array}$ & $\begin{array}{c}\text { In the subgroup analysis for therapy } \\
\text { duration }>14 \text { days, significant } \\
\text { reduction in the combined outcome } \\
\text { of mortality or BPD at } 36 \text { weeks } \\
\text { PMA ( } 3 \text { studies, } 428 \text { patients) (TRR } \\
0.76,95 \% \mathrm{Cl} 0.59-0.98 \text { ) and in BPD } \\
\text { rates alone (TRR } 0.72,95 \% \mathrm{Cl} \\
0.54-0.97 \text { ) } \\
\text { Reduction in extubation failure (TRR } \\
0.51,95 \% \mathrm{Cl} 0.37-0.70 \text { ) }\end{array}$ & $\begin{array}{c}\text { No difference in mortality at } \\
\text { discharge or at } 12 \text { months } \\
\text { Increased risk of tachycardia in the } \\
\text { HD group (RR } 3.39,95 \% \mathrm{Cl} \\
1.50-7.64 \text { ) } \\
\text { No difference in NEC, SIP, ROP, IVH, } \\
\text { hyperglycaemia. } \\
\text { Considerations: no meta-analysis on } \\
\text { differences in apnoea frequency } \\
\text { due to diverse definition of the } \\
\text { outcome } \\
\text { No meta-analysis on duration of } \\
\text { respiratory support due to data } \\
\text { reported in IQR } \\
\text { Inadequate power to detect small but } \\
\text { clinical relevant differences } \\
\text { Considerable differences in } \\
\text { administered caffeine doses } \\
\text { between studies }\end{array}$ \\
\hline
\end{tabular}


TABLE 2 Continued

\begin{tabular}{|c|c|c|c|c|c|}
\hline \multirow{2}{*}{$\begin{array}{l}\text { First author, } \\
\text { year [ref.] }\end{array}$} & \multirow{2}{*}{$\begin{array}{c}\text { Study characteristics } \\
\text { Patient characteristics } \\
\text { Limitations }\end{array}$} & \multicolumn{2}{|c|}{ Regimen } & \multicolumn{2}{|c|}{ Main significant findings } \\
\hline & & High caffeine dose & $\begin{array}{l}\text { Standard/low } \\
\text { caffeine dose }\end{array}$ & Benefits of high caffeine dose & $\begin{array}{l}\text { Drawbacks or no effects of high } \\
\text { caffeine dose }\end{array}$ \\
\hline $\begin{array}{l}\text { BRATTSTRöM, } \\
2019 \text { [87] }\end{array}$ & $\begin{array}{l}\text { Systematic review and meta-analysis } \\
\text { including } 6 \text { RCTs with a total of } 816 \\
\text { preterm infants (GA } \leqslant 32 \mathrm{GW} \text { ) LD } \\
20-80 \mathrm{mg} \cdot \mathrm{kg}^{-1} ; \text { MD } 3-20 \mathrm{mg} \cdot \mathrm{kg}^{-1} \\
\text { Low quality of evidence mainly due to } \\
\text { imprecision of the estimates, few events, } \\
\text { small sample sizes and the wide } \\
\text { confidence intervals of the meta-analysis }\end{array}$ & $\begin{array}{l}\mathrm{LD}>20 \mathrm{mg} \cdot \mathrm{kg}^{-1} \\
\mathrm{MD}>10 \mathrm{mg} \cdot \mathrm{kg}^{-1}\end{array}$ & $\begin{array}{l}\text { Doses lower than the } \\
\text { high-caffeine group }\end{array}$ & $\begin{array}{c}\text { Reduction in BPD at } 36 \text { weeks PMA } \\
\text { (RR } 0.76,95 \% \mathrm{CI} 0.60-0.96 \text { ) } \\
\text { Fewer cases of extubation failure las } \\
\text { defined by study authors, RR } 0.51 \text {, } \\
95 \% \mathrm{Cl} 0.36-0.71 \text { ) and apnoeas } \\
\text { (mean difference }-5.68,-6.15- \\
5.22 \text { ), and shorter duration of MV } \\
\text { (mean difference }-1.69,-2.13- \\
1.25 \text { ) in the HD group }\end{array}$ & $\begin{array}{r}\text { No difference in mortality (RR } 0.85 \text {, } \\
95 \% \mathrm{Cl} 0.53-1.38 \text { ) } \\
\text { No difference in IVH } \geqslant 3 \text { (RR } 1.41,95 \% \\
\mathrm{Cl} 0.71-2.79 \text { ) }\end{array}$ \\
\hline $\begin{array}{l}\text { CHEN, } 2018 \\
\text { [92] }\end{array}$ & $\begin{array}{c}\text { Systematic review and meta-analysis } \\
\text { including } 13 \text { RCTs with } 1515 \text { infants, GA } \\
\qquad<32 \mathrm{GW} \\
\text { Variable maintenance doses within the } \\
\text { high- and low-dose range; only few trials } \\
\text { assessing outcomes such as extubation } \\
\text { failure, frequency of apnoea, apnoea } \\
\text { duration; most studies in Chinese with } \\
\text { low quality }\end{array}$ & $\begin{array}{c}\text { Variable LD } \\
\text { MD 10-20 } \mathrm{mg} \cdot \mathrm{kg}^{-1}\end{array}$ & $\begin{array}{c}\text { Variable LD } \\
\text { MD } 5-10 \mathrm{mg} \cdot \mathrm{kg}^{-1}\end{array}$ & $\begin{array}{c}\text { Higher efficacy rate in the } \mathrm{HD} \text { group } \\
\text { (RR 1.37, } 95 \% \mathrm{Cl} 1.18-1.45 \text { ) } \\
\text { Higher success rate of ventilator } \\
\text { removal (3 studies, RR } 1.74,95 \% \mathrm{Cl} \\
1.04-2.90 \text { ) } \\
\text { Lower extubation failure rate in the } \mathrm{HD} \\
\text { group (3 studies, RR } 0.5,95 \% \mathrm{Cl} \\
0.35-0.71 \text { ) } \\
\text { Lower frequency of apnoea and } \\
\text { shorter apnoea duration in the } \mathrm{HD} \\
\text { group (MD }-1.55,95 \% \mathrm{Cl} \\
-2.72--0.39 \text { and } \mathrm{MD}-4.85,95 \% \mathrm{Cl} \\
\quad-8.29--1.40 \text { ) } \\
\text { Lower incidence of } \mathrm{BPD} \text { in the } \mathrm{HD} \\
\text { group (RR } 0.79,95 \% \mathrm{Cl} 0.68-0.91 \text { ) }\end{array}$ & $\begin{array}{c}\text { Higher incidence of tachycardia in } \\
\text { the HD group (RR 2.02, 95\% Cl } \\
1.30-3.12 \text { ) }\end{array}$ \\
\hline
\end{tabular}

GW: gestational weeks; LD: loading dose; MD: maintenance dose; RR: risk ratio; NNT: number needed to treat; MV: mechanical ventilation; BPD: bronchopulmonary dysplasia; ROP: retinopathy of prematurity; IVH: intraventricular haemorrhage; PVL: periventricular leukomalacia; LOS: late-onset sepsis; CLD: chronic lung disease; GRADE: Grading of Recommendations Assessment, Development and Evaluation; PMA: post-menstrual age; TRR: typical risk ratio; HD: high dose; NEC: necrotising enterocolitis; SIP: spontaneous intestinal perforation; IQR: interquartile range; GA: gestational age. 


\section{Caffeine pharmacokinetics}

\section{Caffeine metabolism and pharmacokinetics}

Most of the studies investigating the metabolism of caffeine in premature newborns were conducted between the 1970s and the 1990s by ARANDA and co-workers [93, 94]. Using high-performance liquid chromatography (HPLC), these authors were able to show a strict correlation between administered dose of drug and plasma level [77], as well as between plasma and cerebrospinal fluid levels [95]. The route of caffeine administration does not affect its pharmacokinetics, as there is almost complete bioavailability after its oral or i.v. administration. Oral caffeine citrate is rapidly and completely absorbed by the gastrointestinal tract, as there is almost no first-pass metabolism, with the peak plasma concentration often reached in $<1 \mathrm{~h}[96]$.

Caffeine metabolism occurs in the liver, mainly by CYP1A2, with a subsequent $\mathrm{N}$-demethylation at positions 1,3 and 7 and hydroxylation at position 8 . In preterm neonates, $\sim 86 \%$ of caffeine citrate is excreted unchanged in the urine [97], as the processes of caffeine metabolism maturates progressively through time (N7-demethylation at the post-natal age of $\sim 4$ months [98], acetylation by $\mathrm{N}$-acetyltransferase (NAT2) completely developed by 1 year of postnatal age [99] and 8-hydroxylation activity starting as early as 1 month of age [100]). Thus, the maturity of the hepatic enzymes, dependent mainly by the postnatal age regardless of birthweight and gestational age, affects the plasma half-life of the drug $[98,101]$.

Due to this difference in metabolism, and to the slow urinary excretion of unmetabolised drug at the earlier gestational ages, the serum half-life of caffeine in infants ranges from 40 to $230 \mathrm{~h}$ ( $>17$-fold greater than that in adults), decreasing with the advance of PMA to $\sim 2-4 \mathrm{~h}$ by $6-8$ months [102]. Of note, because of the long half-life, caffeine may persist in an infant's plasma for some days after cessation of therapy $[102,103]$.

Elimination of caffeine occurs mainly by renal excretion in the first weeks of life, which is slower in premature and term neonates compared with older children and adults, because of immaturity of renal functions [96]. Clearance of caffeine in neonates is influenced by gestational age, postconceptional age, parenteral nutrition and comorbidities [96, 99, 100, 103, 104], with values ranging from 0.08 to $0.13 \mathrm{~mL} \cdot \mathrm{kg}^{-1} \cdot \mathrm{min}^{-1}$ compared to that of adults and older children of 1.5 and $4.4 \mathrm{~mL} \cdot \mathrm{kg}^{-1} \cdot \mathrm{min}^{-1}$, respectively $[100,105]$.

These data highlight that extremely premature infants do not behave as "little adults" with respect to caffeine pharmacokinetics, as caffeine metabolism and urinary elimination are strongly determined by the maturity of liver enzymes and renal function, which are influenced by gestational and postnatal age and by the presence of morbidities affecting these organs.

\section{Therapeutic drug monitoring}

Caffeine dosing and therapeutic drug monitoring (TDM) vary from practice to practice. Caffeine has a wider therapeutic range than theophylline, therefore the role of TDM for the control of therapeutic ranges of caffeine has often been challenged [106]. A therapeutic level of caffeine is considered between 5 and $25 \mathrm{mg} \cdot \mathrm{L}^{-1}$ (or $\mu \mathrm{g} \cdot \mathrm{mL}^{-1}$ ), while toxic levels are reached with $>40-50 \mathrm{mg} \cdot \mathrm{L}^{-1}[107,108]$. An observational study by Natarajan et al. [109] in neonates born between 23 and $32 \mathrm{GW}$ found that caffeine citrate doses of $2.5-10.9 \mathrm{mg} \cdot \mathrm{kg}^{-1}$ (median $5 \mathrm{mg} \cdot \mathrm{kg}^{-1}$ ), obtained plasma levels ranging between 5.1 and $20 \mathrm{mg} \cdot \mathrm{L}^{-1}$ in $94.8 \%$ of cases (within the normal therapeutic ranges), independent of gestation, thus indicating against the necessity of TDM. However, in the subgroup of infants in whom caffeine plasma concentrations were obtained for lack of clinical efficacy, three-quarters of the levels were within the normal range $\left(15 \mathrm{mg} \cdot \mathrm{L}^{-1}\right)$, which suggests that higher doses and plasma concentrations may be required for optimal efficacy in some preterm neonates. In addition, the numbers of infants with renal or hepatic dysfunction in the study were small at the time of caffeine level, and no data on relation to efficacy with regard to apnoea was reported. Importantly, another study demonstrated that a standardised regimen leads to a high variation of serum levels of caffeine metabolites in infants $<33 \mathrm{GW}$, with no correlation between episodes of apnoea and caffeine serum concentrations in the post-extubation period [110]. Therefore, caffeine TDM may help dose individualisation in order to minimise the incidence of toxic adverse effects, optimise efficacy and the performance of diagnostic tests, especially for patients who are unresponsive to therapy (breakthrough apnoea, bradycardia or desaturations without other obvious disease-related aetiologies) $[106,111,112]$. In addition, a retrospective chart review of infants born $\leqslant 29 \mathrm{GW}$ demonstrated that those with an average caffeine concentration $>14.5 \mu \mathrm{g} \cdot \mathrm{mL}^{-1}$ had lower incidence of chronic lung disease and PDA, lesser number of days on ventilator and oxygen, less need for diuretics and lower length of stay and total hospital charges $($ all $\mathrm{p}<0.05)$ [113]. If these findings are confirmed prospectively, it could become useful to introduce TDM in routine practice. 
Caffeine levels can be measured in plasma, saliva or urine by enzyme immunoassay technique, which is simple, convenient and rapid, or using HPLC, which is the most accurate technique for caffeine TDM in the clinical setting $[114,115]$. In recent years, minimally invasive techniques have been proposed for the detection of caffeine levels, with promising results. In 2013, Patel et al. [116] used dried blood spots (DBS) to measure caffeine dosage with liquid chromatography triple quadrupole mass spectrometry from 67 preterm infants at random time intervals following either oral or i.v. doses. The study showed a good agreement between pharmacokinetic parameters estimated using DBS samples and historical caffeine pharmacokinetic parameters based on plasma samples.

In 2016, BRUSCHETTINI et al. [117] confirmed the importance of limiting the size of blood samples to avoid anaemia due to blood sampling for TDM in preterm infants and highlighted the advantages of DBS over conventional sampling techniques. To overcome the problem of haematocrit, alternative strategies based on new microfluidic sampling procedures or volumetric microsampling devices have been described and proved to be a reliable sampling approach for caffeine $[118,119]$; however, the drawback is the use of expensive devices for routine TDM analyses or for pharmacokinetic studies. To overcome the problem of blood sample size, invasiveness and cost, in 2017, CHAABAne et al. [120] determined caffeine concentrations in both saliva and serum of preterm infants (mean gestational age $32.2 \pm 0.7$ weeks), showing a proportional increase in both saliva and serum caffeine concentration to the administered dose, with the saliva caffeine concentrations strongly correlating with those from serum.

Despite different studies exploring the best minimally invasive and cost-effective methods to monitor therapeutic ranges of caffeine in clinical practice, few have tried to develop a pharmacokinetic model to adjust caffeine dosage and none has investigated the relationship between caffeine biofluid levels in the first weeks of life and clinical outcomes, such as apnoea frequency [121, 122]. Interestingly, in $2017 \mathrm{KoCH}$ et al. [122] developed simulation models of caffeine concentrations, proposing the need of adjusting the maintenance doses through time in preterm neonates, with the administration of $6 \mathrm{mg} \cdot \mathrm{kg}^{-1} \cdot \mathrm{day}^{-1}$ in the second week of life, $7 \mathrm{mg} \cdot \mathrm{kg}^{-1} \cdot \mathrm{day}^{-1}$ in weeks $3-4$ and $8 \mathrm{mg} \cdot \mathrm{kg}^{-1} \cdot$ day $^{-1}$ in weeks $5-8$.

Further studies are needed to determine whether caffeine dosage can be optimised for the individual patient through TDM in particular situations. Drug levels could be performed minimising the drawn blood volume (for instance with DBS) or, even better, non-invasively (for example in urine or saliva samples). Prospective pharmacokinetic studies of caffeine with relation to both clinical outcomes (apnoea episodes, extubation failure, respiratory support at 36 weeks PMA, respiratory morbidity in the first year of life), and adverse events (tachycardia, hypoglycaemia, seizures, weight loss, neurodevelopment at 2 and 5 years) should be conducted in order to identify the appropriate dosage of the drug.

\section{Conclusions}

In preterm infants, caffeine is effective in reducing apnoea frequency, the need for IPPV and mechanical ventilation, as well as enhancing the success of extubation. In addition, caffeine-treated newborns have lower rates of BPD, IVH and PDA, with positive long-term outcomes on pulmonary function and neurodevelopment. Despite the longstanding use of caffeine in the neonatal intensive care units, controversies regarding the optimal timing and dosage of caffeine therapy still remain [123], as the majority of data on long-term outcomes and safety stem from one randomised placebo-controlled trial [33]. Furthermore, the role of therapeutic drug monitoring needs to be addressed. The paucity of data on caffeine metabolism related to clinical outcomes in extremely preterm neonates highlights the importance of further research in this field in order to better refine the respiratory management of these subjects.

Support statement: The authors gratefully acknowledge that L. Moschino is the recipient of the European Respiratory Society Short-term Research Fellowship 2017, and C. Hartley received grants from The Wellcome Trust and the Royal Society during the writing of the manuscript.

Conflict of interest: L. Moschino reports an ERS Short-Term Research Fellowship 2017 during the writing of this article. S. Zivanovic has nothing to disclose. C. Hartley reports grants from The Wellcome Trust and the Royal Society during the writing of this article. D. Trevisanuto has nothing to disclose. E. Baraldi has nothing to disclose. C.C. Roehr reports that donations for processing laboratory samples were received from Chiesi Pharmaceuticals (Parma, Italy) for conducting an investigator-initiated study on caffeine metabolism in newborn infants. None of the content of this review relates to the company, their donation or the product they distribute. The company has not been involved in the writing of the review.

\section{References}

1 Frey HA, Klebanoff MA. The epidemiology, etiology, and costs of preterm birth. Semin Fetal Neonatal Med 2016; 21: $68-73$.

2 European Respiratory Society. Prevention. In: European Respiratory Roadmap for Health Policy Makers 2011 www.ersnet.org/roadmap 
World Health Organization (WHO). WHO Recommendations on Interventions to Improve Preterm Birth Outcomes. Geneva, WHO, 2015.

4 Decramer M, European Respiratory Roadmap Initiative. The European respiratory roadmap. Lancet 2011; 378: 1765-1772.

5 Schmalisch G, Wilitzki S, Roehr CC, et al. Differential effects of immaturity and neonatal lung disease on the lung function of very low birth weight infants at 48-52 postconceptional weeks. Pediatr Pulmonol 2013; 48: 1214-1223.

6 Baraldi E, Filippone M. Chronic lung disease after premature birth. N Engl J Med 2007; 357: $1946-1955$.

7 Moschino L, Stocchero M, Filippone M, et al. Longitudinal assessment of lung function in survivors of bronchopulmonary dysplasia from birth to adulthood. The Padova BPD Study. Am J Respir Crit Care Med 2018; 198: 134-137.

8 Roehr CC, Bohlin K. Neonatal resuscitation and respiratory support in prevention of bronchopulmonary dysplasia. Breathe 2011; 8: 14-23.

9 Trevisanuto D, Satariano I, Doglioni N, et al. Changes over time in delivery room management of extremely low birth weight infants in Italy. Resuscitation 2014; 85: 1072-1076.

10 Morley CJ, Davis PG, Doyle LW, et al. Nasal CPAP or intubation at birth for very preterm infants. $N$ Engl J Med 2008; 358: 700-708.

11 SUPPORT Study Group of the Eunice Kennedy Shriver NICHD Neonatal Research Network, Finer NN, Carlo WA, et al. Early CPAP versus surfactant in extremely preterm infants. N Engl J Med 2010; 362: 1970-1979.

12 Dekker J, Hooper SB, van Vonderen JJ, et al. Caffeine to improve breathing effort of preterm infants at birth: a randomized controlled trial. Pediatr Res 2017; 82: 290-296.

13 Eichenwald EC, Committee on Fetus and Newborn, American Academy of Pediatrics. Apnea of prematurity. Pediatrics 2016; 137: e20153757.

14 Regenbogen E, Zhang S, Yang J, et al. Epidemiological trends among preterm infants with apnea. A twelve-year database review. Int J Pediatr Otorhinolaryngol 2018; 107: 86-92.

15 Henderson-Smart DJ, De Paoli AG. Methylxanthine treatment for apnoea in preterm infants. Cochrane Database Syst Rev 2010; 12: CD000140.

16 Hsieh EM, Hornik CP, Clark RH, et al. Medication use in the neonatal intensive care unit. Am J Perinatol 2014 31: 811-821.

17 Weinberg BA, Bealer BK. The World of Caffeine: The Science and Culture of the World's Most Popular Drug. London, Routledge, 2002.

18 Kreutzer K, Bassler D. Caffeine for apnea of prematurity: a neonatal success story. Neonatology 2014; 105: 332-336.

19 Abu-Shaweesh JM, Martin RJ. Caffeine use in the neonatal intensive care unit. Semin Fetal Neonatal Med 2017; 22: $342-347$

20 Atik A, Harding R, De Matteo R, et al. Caffeine for apnea of prematurity: effects on the developing brain Neurotoxicology 2017; 58: 94-102.

21 Parikka V, Beck J, Zhai Q, et al. The effect of caffeine citrate on neural breathing pattern in preterm infants. Early Hum Dev 2015; 91: 565-568.

22 Rieg T, Steigele H, Schnermann J, et al. Requirement of intact adenosine Al receptors for the diuretic and natriuretic action of the methylxanthines theophylline and caffeine. J Pharmacol Exp Ther 2005; 313: 403-409.

23 Back SA, Craig A, Luo NL, et al. Protective effects of caffeine on chronic hypoxia-induced perinatal white matter injury. Ann Neurol 2006; 60: 696-705.

24 Kilicdag H, Daglioglu YK, Erdogan S, et al. Effects of caffeine on neuronal apoptosis in neonatal hypoxic-ischemic brain injury. J Matern Fetal Neonatal Med 2014; 27: 1470-1475.

25 Supcun S, Kutz P, Pielemeier W, et al. Caffeine increases cerebral cortical activity in preterm infants. $J$ Pediatr 2010; 156: 490-491.

26 Hassanein SM, Gad GI, Ismail RI, et al. Effect of caffeine on preterm infants' cerebral cortical activity: an observational study. J Matern Fetal Neonatal Med 2015; 28: 2090-2095.

27 Schmidt B, Roberts RS, Davis P, et al. Long-term effects of caffeine therapy for apnea of prematurity. $N$ Engl Med 2007; 357: 1893-1902.

28 Schmidt B, Anderson PJ, Doyle LW, et al. Survival without disability to age 5 years after neonatal caffeine therapy for apnea of prematurity. JAMA 2012; 307: 275-282.

29 Schmidt B, Roberts RS, Anderson PJ, et al. Academic performance, motor function, and behavior 11 years after neonatal caffeine citrate therapy for apnea of prematurity: an 11-year follow-up of the CAP randomized clinical trial. JAMA Pediatr 2017; 171: 564-572.

30 Mürner-Lavanchy IM, Doyle LW, Schmidt B, et al. Neurobehavioral outcomes 11 years after neonatal caffeine therapy for apnea of prematurity. Pediatrics 2018; 141: e20174047.

31 Gillot I, Gouyon JB, Guignard JP. Renal effects of caffeine in preterm infants. Biol Neonate 1990; 58: 133-136.

32 Dobson NR, Patel RM, Smith PB, et al. Trends in caffeine use and association between clinical outcomes and timing of therapy in very low birth weight infants. J Pediatr 2014; 164: 992-998.

33 Schmidt B, Roberts RS, Davis P, et al. Caffeine therapy for apnea of prematurity. N Engl J Med 2006; 354: 2112-2121.

34 Davis PG, Schmidt B, Roberts RS, et al. Caffeine for Apnea of Prematurity trial: benefits may vary in subgroups J Pediatr 2010; 156: 382-387.

35 Henderson-Smart DJ, De Paoli AG. Prophylactic methylxanthine for prevention of apnoea in preterm infants Cochrane Database Syst Rev 2010; 12: CD000432.

36 Henderson-Smart DJ, Davis PG. Prophylactic methylxanthines for endotracheal extubation in preterm infants Cochrane Database Syst Rev 2010; 12: CD000139.

37 Doyle LW, Ranganathan S, Cheong JLY. Neonatal caffeine treatment and respiratory function at 11 years in children under 1,251 g at birth. Am J Respir Crit Care Med 2017; 196: 1318-1324.

38 Walther FJ, Erickson R, Sims ME. Cardiovascular effects of caffeine therapy in preterm infants. Am J Dis Child 1990; 144: 1164-1166.

39 Soloveychik V, Bin-Nun A, Ionchev A, et al. Acute hemodynamic effects of caffeine administration in premature infants. J Perinatol 2009; 29: 205-208. 
Katheria AC, Sauberan JB, Akotia D, et al. A pilot randomized controlled trial of early versus routine caffeine in extremely premature infants. Am I Perinatol 2015; 32: 879-886.

Connolly S, Kingsbury TJ. Caffeine modulates CREB-dependent gene expression in developing cortical neurons. Biochem Biophys Res Commun 2010; 397: 152-156.

Endesfelder S, Weichelt U, Strauß E, et al. Neuroprotection by caffeine in hyperoxia-induced neonatal brain injury. Int J Mol Sci 2017; 18: E187.

Silva CG, Métin C, Fazeli W, et al. Adenosine receptor antagonists including caffeine alter fetal brain development in mice. Sci Transl Med 2013; 5: 197 ra104.

Rhein LM, Dobson NR, Darnall RA, et al. Effects of caffeine on intermittent hypoxia in infants born prematurely: a randomized clinical trial. JAMA Pediatr 2014; 168: 250-257.

Poets CF, Roberts RS, Schmidt B, et al. Association between intermittent hypoxemia or bradycardia and late death or disability in extremely preterm infants. JAMA 2015; 314: 595-603.

Kumar VHS, Lipshultz SE. Caffeine and clinical outcomes in premature neonates. Children 2019; 6: E118.

Schmidt B. Methylxanthine therapy for apnea of prematurity: evaluation of treatment benefits and risks at age 5 years in the international Caffeine for Apnea of Prematurity (CAP) trial. Biol Neonate 2005; 88: 208-213.

Levitt G, Mushin A, Bellman S, et al. Outcome of preterm infants who suffered neonatal apnoeic attacks. Early Hum Dev 1988; 16: 235-243.

Armanian AM, Iranpour R, Faghihian E, et al. Caffeine administration to prevent apnea in very premature infants. Pediatr Neonatol 2016; 57: 408-412.

Committee on Fetus and Newborn. American Academy of Pediatrics. Apnea, sudden infant death syndrome, and home monitoring. Pediatrics 2003; 111: 914-922.

Murat I, Moriette G, Blin MC, et al. The efficacy of caffeine in the treatment of recurrent idiopathic apnea in premature infants. J Pediatr 1981; 99: 984-999.

Erenberg A, Leff RD, Haack DG, et al. Caffeine citrate for the treatment of apnea of prematurity: a double-blind placebo-controlled study. Pharmacotherapy 2000; 20: 644-652.

Muro M, Perez-Rodriguez J, Garcia MJ, et al. Efficacy of caffeine for weaning premature infants from mechanical ventilation. Effects on pulmonary function. J Perinat Med 1992; 20: 315.

Shennan AT, Dunn MS, Ohlsson A, et al. Abnormal pulmonary outcomes in premature infants: prediction from oxygen requirement in the neonatal period. Pediatrics 1988; 82: 527-532. evidence-based approach. Am J Respir Crit Care Med 2019; 200: 751-759.

Poets CF, Lorenz L. Prevention of bronchopulmonary dysplasia in extremely low gestational age neonates: current evidence. Arch Dis Child Fetal Neonatal Ed 2018; 103: F285-F291.

Lodha A, Seshia M, McMillan DD, et al. Association of early caffeine administration and neonatal outcomes in very preterm neonates. JAMA Pediatr 2015; 169: 33-38.

Jobe AH. Caffeine: a lung drug for all very low birth weight preterm infants? Am J Respir Crit Care Med 2017; 196: 1241-1243.

Sweet DG, Carnielli V, Greisen G, et al. European Consensus Guidelines on the Management of Respiratory Distress Syndrome - 2019 update. Neonatology 2019; 115: 432-451.

National Institute for Health and Care Excellence (NICE). NICE Guideline [NG124]. Specialist Neonata Respiratory Care for Babies Born Preterm. www.nice.org.uk/guidance/ng124 Date last updated: April 2019. Date last accessed: November 11, 2019.

Patel RM, Leong T, Carlton DP, et al. Early caffeine therapy and clinical outcomes in extremely preterm infants. J Perinatol 2013; 33: 134-140.

Lodha A, Entz R, Synnes A, et al. Early caffeine administration and neurodevelopmental outcomes in preterm infants. Pediatrics 2019; 143: e20181348.

Borszewska-Kornacka MK, Hożejowski R, Rutkowska M, et al. Shifting the boundaries for early caffeine initiation in neonatal practice: results of a prospective, multicentre study on very preterm infants with respiratory distress syndrome. PLoS One 2017; 12: e0189152.

Park HW, Lim G, Chung SH, et al. Early caffeine use in very low birth weight infants and neonatal outcomes: a systematic review and meta-analysis. J Korean Med Sci 2015; 30: 1828-1835.

Abbasi S, Aden U, Allan W, et al. Early caffeine is associated with decreased IVH in very low birth weight neonate. Ann Neurol 2010; 68: S88-S90.

Taha D, Kirkby S, Nawab U, et al. Early caffeine therapy for prevention of bronchopulmonary dysplasia in preterm infants. J Matern Fetal Neonatal Med 2014; 27: 1698-1702.

Kua KP, Lee SW. Systematic review and meta-analysis of clinical outcomes of early caffeine therapy in preterm neonates. Br J Clin Pharmacol 2017; 83: 180-191.

Gupte AS, Gupta D, Ravichandran S, et al. Effect of early caffeine on neurodevelopmental outcome of very low-birth weight newborns. J Matern Fetal Neonatal Med 2016; 29: 1233-1237.

Saeidi R, Maghrebi S. Comparison of the early and late caffeine therapy on clinical outcomes in preterm neonates. Giornale Italiano di Ostetricia e Ginecologia 2014; 36: 568-570.

Pakvasa MA, Saroha V, Patel RM. Optimizing caffeine use and risk of bronchopulmonary dysplasia in preterm infants: a systematic review, meta-analysis, and application of Grading of Recommendations Assessment, Development, and Evaluation methodology. Clin Perinatol 2018; 45: 273-291.

Hand I, Zaghloul N, Barash L, et al. Timing of caffeine therapy and neonatal outcomes in preterm infants: a retrospective study. Int J Pediatr 2016; 2016: 9478204.

Dobson NR, Hunt CE. Caffeine: an evidence-based success story in VLBW pharmacotherapy. Pediatr Res 2018; 84: 333-340.

Patel RM, Zimmerman K, Carlton DP, et al. Early caffeine prophylaxis and risk of failure of initial continuous positive airway pressure in very low birth weight infants. J Pediatr 2017; 190: 108-111.

Amaro CM, Bello JA, Jain D, et al. Early caffeine and weaning from mechanical ventilation in preterm infants: a randomized, placebo-controlled trial. J Pediatr 2018; 196: 52-57.

Jain VG, Saroha V, Patel RM, et al. Is early caffeine therapy safe and effective for ventilated preterm infants? Perinatol 2019; 39: 754-757. 
Aranda JV, Gorman W, Bergsteinsson H, et al. Efficacy of caffeine in treatment of apnea in the low-birth-weight infant. J Pediatr 1977; 90: 467-472.

Turmen T, Davis J, Aranda JV. Relationship of dose and plasma concentrations of caffeine and ventilation in neonatal apnea. Semin Perinatol 1981; 5: 326-331.

Caffeine Citrate. www.drugs.com/pro/caffeine-citrate.html Date last accessed: November 11, 2019. Date last updated: March 1, 2019.

Hey E, Ed. Neonatal Formulary. 6th edn. Chichester, John Wiley \& Sons, 2011; p. 64. $425-428$.

, Morgan ME, et al. Caffeine or theophylline for neonatal apnoea? Arch Dis Child 1992; 67:

response trial. J Paediatr Child Health 2003; 39: 511-515.

Steer P, Flenady V, Shearman A, et al. High dose caffeine citrate for extubation of preterm infants: a randomised controlled trial. Arch Dis Child Fetal Neonatal Ed 2004; 89: F499-F503.

Mohammed S, Nour I, Shabaan AE, et al. High versus low-dose caffeine for apnea of prematurity: a randomized controlled trial. Eur J Pediatr 2015; 174: 949-956.

Vliegenthart R, Miedema M, Hutten GJ, et al. High versus standard dose caffeine for apnoea: a systematic review. Arch Dis Child Fetal Neonatal Ed 2018; 103: F523-F529.

McPherson C, Neil JJ, Tjoeng TH, et al. A pilot randomized trial of high-dose caffeine therapy in preterm infants. Pediatr Res 2015; 78: 198-204

Firman B, Molnar A, Gray PH. Early high-dose caffeine citrate for extremely preterm infants: neonatal and neurodevelopmental outcomes. J Paediatr Child Health 2019; 55: 1451-1457.

Brattström P, Russo C, Ley D, et al. High- versus low-dose caffeine in preterm infants: a systematic review and meta-analysis. Acta Paediatr 2019; 108: 401-410.

Romagnoli C, De Carolis MP, Muzii U, et al. Effectiveness and side effects of two different doses of caffeine in preventing apnea in premature infants. Ther Drug Monit 1992; 14: 14-19.

Gray PH, Flenady VJ, Charles BG, et al. Caffeine citrate for very preterm infants: effects on development, temperament and behaviour. J Paediatr Child Health 2011; 47: 167-172.

Zhao Y, Tian X, Liu G. [Clinical effectiveness of different doses of caffeine for primary apnea in preterm infants]. Zhonghua Er Ke Za Zhi 2016; 54: 33-36.

Jobe AH, Bancalari E. Bronchopulmonary dysplasia. Am J Respir Crit Care Med 2001; 163: 1723-1729.

Chen J, Jin L, Chen X. Efficacy and safety of different maintenance doses of caffeine citrate for treatment of apnea in premature infants: a systematic review and meta-analysis. Biomed Res Int 2018; 2018: 9061234.

Aranda JV, Beharry K, Valencia GB, et al. Caffeine impact on neonatal morbidities. J Matern Fetal Neonatal Med 2010; 23: Suppl. 3, 20-23.

Aranda JV, Cook CE, Gorman W, et al. Pharmacokinetic profile of caffeine in the premature newborn infant with apnea. J Pediatr 1979; 94: 663-668. apnea. J Pediatr 1979; 95: 644-646.

Abdel-Hady H, Nasef N, Shabaan AE, et al. Caffeine therapy in preterm infants. World J Clin Pediatr 2015; 4: 81-93.

Young TE, Mangum B. Neofax: a Manual of Drugs Used in Neonatal Care. Respiratory Drugs. 23rd edn. Montvale, NJ, USA, Thomson Reuters, 2010; pp. 272-273.

al-Alaiyan S, al-Rawithi S, Raines D, et al. Caffeine metabolism in premature infants. J Clin Pharmacol 2001; 41: 620-627.

Pons G, Rey E, Carrier O, et al. Maturation of AFMU excretion in infants. Fundam Clin Pharmacol 1989; 3 : 589-595.

Pacifici GM. Clinical pharmacology of caffeine citrate in preterm infants. MedicalExpress 2014; 1: 243-250.

Shrestha B, Jawa G. Caffeine citrate - is it a silver bullet in neonatology? Pediatr Neonatol 2017; 58: 391-397.

Doyle J, Davidson D, Katz S, et al. Apnea of prematurity and caffeine pharmacokinetics: potential impact on hospital discharge. J Perinatol 2016; 36: 141-144.

Guennec JC, Billon B, Paré C. Maturational changes of caffeine concentrations and disposition in infancy during maintenance therapy for apnea of prematurity: influence of gestational age, hepatic disease, and breast-feeding. Pediatrics 1985; 76: 834-840.

Arant BS. Developmental patterns of renal functional maturation compared in the human neonate. J Pediatr 1978; 92: 705-712.

Johnson PJ. Caffeine citrate therapy for apnea of prematurity. Neonatal Netw 2011; 30: 408-412.

Gal P. Caffeine therapeutic drug monitoring is necessary and cost-effective. J Pediatr Pharmacol Ther 2007; 12: 212-215.

Charles BG, Townsend SR, Steer PA, et al. Caffeine citrate treatment for extremely premature infants with apnea: population pharmacokinetics, absolute bioavailability, and implications for therapeutic drug monitoring. Ther Drug Monit 2008; 30: 709-716.

Lee TC, Charles B, Steer P, et al. Population pharmacokinetics of intravenous caffeine in neonates with apnea of prematurity. Clin Pharmacol Ther 1997; 61: 628-640.

Natarajan G, Botica ML, Thomas R, et al. Therapeutic drug monitoring for caffeine in preterm neonates: an unnecessary exercise? Pediatrics 2007; 119: 936-940

Yu T, Balch AH, Ward RM, et al. Incorporating pharmacodynamic considerations into caffeine therapeutic drug monitoring in preterm neonates. BMC Pharmacol Toxicol 2016; 17: 22.

Pesce AJ, Rashkin M, Kotagal U. Standards of laboratory practice: theophylline and caffeine monitoring. Clin Chem 1998; 44: 1124-1128.

Leon AE, Michienzi K, Ma CX, et al. Serum caffeine concentrations in preterm neonates. Am J Perinatol 2007; 24: 39-47.

Alur P, Bollampalli V, Bell T, et al. Serum caffeine concentrations and short-term outcomes in premature infants of $\leqslant 29$ weeks of gestation. J Perinatol 2015; 35: 434-438.

A Ther Drug Monit 1987; 9: 97-103. 
115 Gorodischer R, Karplus M. Pharmacokinetic aspects of caffeine in premature infants with apnoea. Eur J Clin Pharmacol 1982; 22: 47-52.

116 Patel P, Mulla H, Kairamkonda V, et al. Dried blood spots and sparse sampling: a practical approach to estimating pharmacokinetic parameters of caffeine in preterm infants. Br J Clin Pharmacol 2013; 75: 805-813.

117 Bruschettini M, Barco S, Romantsik O, et al. DBS-LC-MS/MS assay for caffeine: validation and neonatal application. Bioanalysis 2016; 8: 1893-1902.

118 Leuthold LA, Heudi O, Déglon J, et al. New microfluidic-based sampling procedure for overcoming the haematocrit problem associated with dried blood spot analysis. Anal Chem 2015; 87: 2068-2071.

119 De Kesel PM, Lambert WE, Stove CP. Does volumetric absorptive microsampling eliminate the hematocrit bias for caffeine and paraxanthine in dried blood samples? A comparative study. Anal Chim Acta 2015; 881: 65-73.

120 Chaabane A, Chioukh FZ, Chadli Z, et al. Therapeutic drug monitoring of caffeine in preterm infants: could saliva be an alternative to serum? Therapie 2017; 72: 685-689.

121 Wilhelm AJ, den Burger JC, Swart EL. Therapeutic drug monitoring by dried blood spot: progress to date and future directions. Clin Pharmacokinet 2014; 53: 961-973.

122 Koch G, Datta AN, Jost K, et al. Caffeine citrate dosing adjustments to assure stable caffeine concentrations in preterm neonates. J Pediatr 2017; 191: 50-56.

123 Gentle SJ, Travers CP, Carlo WA. Caffeine controversies. Curr Opin Pediatr 2018; 30: 177-181. 